\title{
Review
}

\section{The brain within the tumor: new roles for axon guidance molecules in cancers}

\author{
A Chédotal ${ }^{*, 1}$, G Kerjan $^{1}$ and C Moreau-Fauvarque ${ }^{1}$ \\ 1 CNRS UMR7102, Equipe Développement Neuronal, Université Paris 6, \\ Batiment B, Case 12, 9 Quai Saint-Bernard, 75005 Paris, France \\ * Corresponding author: A Chédotal, CNRS UMR7102, Equipe Développement \\ Neuronal, Université Paris 6, Batiment B, Case 12, 9 Quai Saint-Bernard, \\ 75005 Paris, France. Tel: + 33-144273414; Fax: + 33-144272636; \\ E-mail: chedotal@infobiogen.fr
}

Received 28.12.04; revised 16.5.05; accepted 25.5.05 Edited by $\mathrm{P}$ Mehlen

\begin{abstract}
Slits, semaphorins and netrins are three families of proteins that can attract or repel growing axons and migrating neurons in the developing nervous system of vertebrates and invertebrates. Recent studies have shown that they are widely expressed outside the nervous system and that they may play important roles in cancers. Several of the genes encoding these proteins are localized on chromosomal region associated with frequent loss-of-heterozygosity in tumors and cancer cell lines and there is also significant hypermethylation of their promoter suggesting that they may act as tumor suppressors. In addition, proteins in all these families and their receptors appear to control the vascularization of the tumors. Last, many axon guidance molecules also regulate cell migration and apoptosis in normal and tumorigenic tissues. Overall, this suggests that molecules that could mimick or block the activity of axon guidance molecules may be used as therapeutic agents for the treatment of malignancy.

Cell Death and Differentiation (2005) 12, 1044-1056.

doi:10.1038/sj.cdd. 4401707
\end{abstract}

Keywords: slit; semaphorin; netrin; plexin; apoptosis; migration; angiogenesis; tumor suppressor

\footnotetext{
Abbreviations: Abl, abelson; AHV, alcelaphine herpes virus; ALPS, agrin/laminin/perlecan/slit; CSPG, chondroitin sulfate proteoglycan; DCC, deleted in colorectal cancer; DNA, desoxyribonucleic acid; Dpp, decapentaplegic; Dutt1, deleted in U2020 cells; FNIII, fibronectin type III; GEF, guanine exchange factor; GPI, glycosyl phosphate inositol ; GTP, guanine tri-phosphate; HSP, heparan sulfate proteoglycan; HUVEC, human umbilical vein endothelial cell; Ig, immunoglobulin; L(2)gl, lethal giant larvae; LG, laminin G; LOH, loss of heterozygosity; LRR, leucine rich repeat domains; MAPK, microtubule associated protein kinase; MDR, multidrug resistance; mRNA, messenger ribonucleic acid; MRS, Met related sequence; NRP1, neuropilin-1; PAE, porcin aortic endothelial; PDZ, PSD-95/DIg/Z0-1; PI3K, phos-
}

phatidyl inositol 3 kinase; PPARs, peroxisome proliferator activated receptors; RGM, Repulsive Guidance Molecule; RNA, ribonucleic acid; Robo, roundabout; SDF-1, stromal-derived factor-1; Sema, semaphorin; TGF, tumor growth factor; TIM, Tcell, immunoglobulin and mucin domain proteins; VEGF, vascular endothelial growth factor

\section{Introduction}

Nervous systems are composed of excitable cells, the neurons, connected by long cellular processes, the axons, that form synaptic networks of increasing complexity from simple invertebrates to primates. However, many cells in the nervous system (up to $90 \%$ in human ${ }^{1}$ ) are not neurons but glia: astrocytes, microglial cells and oligodendrocytes. Astrocytes and microglial cells exert several functions such as the maintenance of brain homeostasis, while oligodendrocytes (that do not exist in invertebrates) produce the myelin that enwraps axons thereby allowing the rapid saltatory conduction of action potentials. During development, all these cells differentiate from multipotent progenitors that proliferate in restricted locations of the embryo. In most animal species, postmitotic neurons and glial cells migrate, sometimes over long distances, to reach their final destination. Concomitantly, neurons extend axons, tipped at their leading edge by a growth cone, toward their target cells, grow dendrites and establish synaptic contacts. All these precisely orchestrated cellular events are regulated by a plethora of secreted and membrane-bound proteins, most of which were identified in the last 10-15 years using genetic and biochemical approaches. ${ }^{2}$ Interestingly, the mechanisms and the molecules that control neural development are highly conserved in evolution. ${ }^{3}$ Recently, it was discovered that many so-called 'axon guidance' molecules also control neuronal migration and neuronal survival. In addition, they are not confined to the nervous system but are widely expressed in many developing and mature organs in the body. ${ }^{4}$ Their normal function in the adult CNS and other adult tissues is essentially unknown. However, an increasing number of studies suggest that they are involved in many pathological processes and in particular cancers.

We will review here recent studies on the function in cancer of three families of axon guidance molecules and their receptors, the netrins, the slits and the semaphorins that have many common properties: most are secreted and all can be repulsive or attractive for growing axons and migrating neurons. Particular attention will be paid to recent data giving new insights on the diversity/complexity of ligand-receptor interactions. The implication of the ephrins and their Eph receptors, another family of axon guidance molecules, in tumorigenesis has been also demonstrated and recently reviewed and will not be discussed here. ${ }^{5}$ 


\section{Semaphorins and their Receptors}

The Semaphorins were simultaneously discovered in insects and chick embryos as very potent axon repellents able to induce the collapse of axonal growth cones. ${ }^{6,7}$ In less than 10 years, more than 30 semaphorins have been cloned in mammals and some orthologs have been found in virtually all animal phyla and in certain DNA viruses. ${ }^{8}$ Eight semaphorin subclasses were distinguished based on sequence similarity and distinctive structural features. ${ }^{9}$ The semaphorin subclasses, 1 and 2, contain semaphorins identified in invertebrate species. Subclasses 3-4-6 and 7 contain vertebrate semaphorins (Figures 1 and 2). Class 5 semaphorins exist both in vertebrate and invertebrate species (Figure 2). All semaphorins share a highly conserved 500 amino-acid motif, the semaphorin domain that is also present in other proteins (Winberg et $a l^{10}$ and Gherardi et al ${ }^{11}$; see below).

Class 3 secreted semaphorins have been by far the most studied and all were shown to be chemorepulsive for many classes of axons (Figure 1). ${ }^{8}$ However, a few semaphorins can also attract some axons and dendrites. ${ }^{12-14}$ Pioneering studies showed that their receptors are multimolecular complexes with neuropilins as binding moieties and plexins as signaling moieties. Among the six class 3 semaphorins identified to date, Sema3A, Sema3C, Sema3D, Sema3E were initially found to bind to neuropilin-1 with similar affinities. ${ }^{15-18}$ A second neuropilin family member, neuropilin-2, which has at least six spliced variants, ${ }^{16,17}$ can bind Sema3C and Sema3F, but not Sema3A with high-affinity. ${ }^{17}$ The cytoplasmic tail of neuropilins is very short but can interact with a cytoplasmic protein containing a central PSD95/Dlg/ZO-1 (PDZ) domain that might work as a molecular adapter coupling neuropilin-1 to membrane trafficking machinery. ${ }^{19}$ Many studies have shown that secreted semaphorin function requires plexins as signaling subunits. Plexins are large membrane spanning proteins with a highly conserved cytoplasmic domain devoid of any obvious enzymatic activity. Their extracellular domain also contains a divergent semaphorin domain and two to three MET-related sequences (MRS, Figure 1). Although plexins do not have kinase activity, they share sequence homology in the extracellular domain with the receptor tyrosine kinases MET (the receptor for scatter factor-1/hepatocyte growth factor) and Ron (the receptor for macrophage-stimulating protein $^{20}$ ). Nine plexins were identified and regrouped into four subclasses (plexin-Aplexin-D). Several studies showed that plexin-A interact with
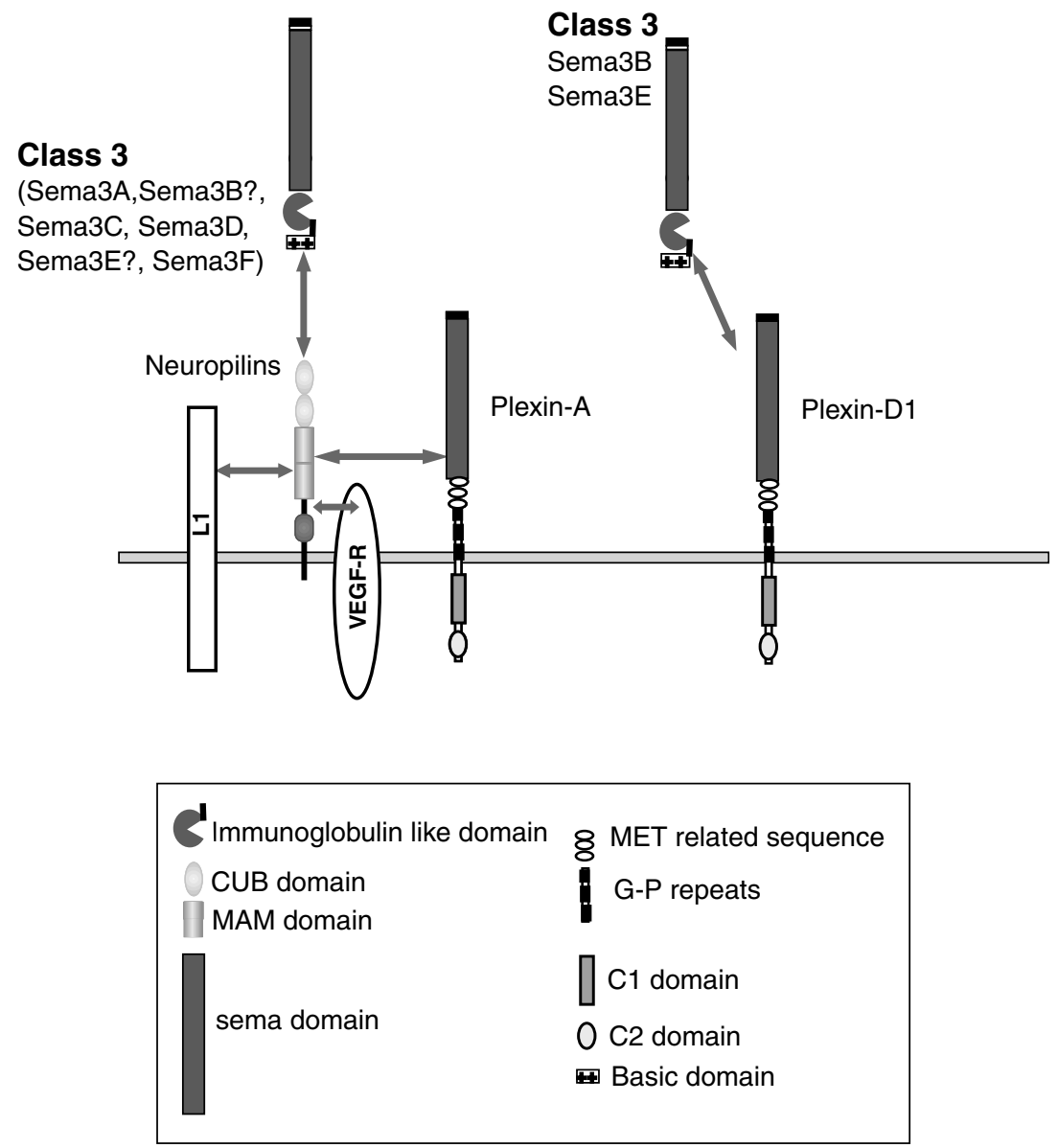

Figure 1 Secreted semaphorins and their receptors. All class 3 semaphorins identified to date were initially found to bind to neuropilins and use plexin-As as signaling subunits. The cell adhesion molecule L1-CAM is also part of the receptor complex for Sema3A. Recent data suggest that, at least in endothelial cells, Sema3E and Sema3B are unable to bind to neuropilins and direct signal through plexin-D1. Neuropilin-1 can also bind VEGF 


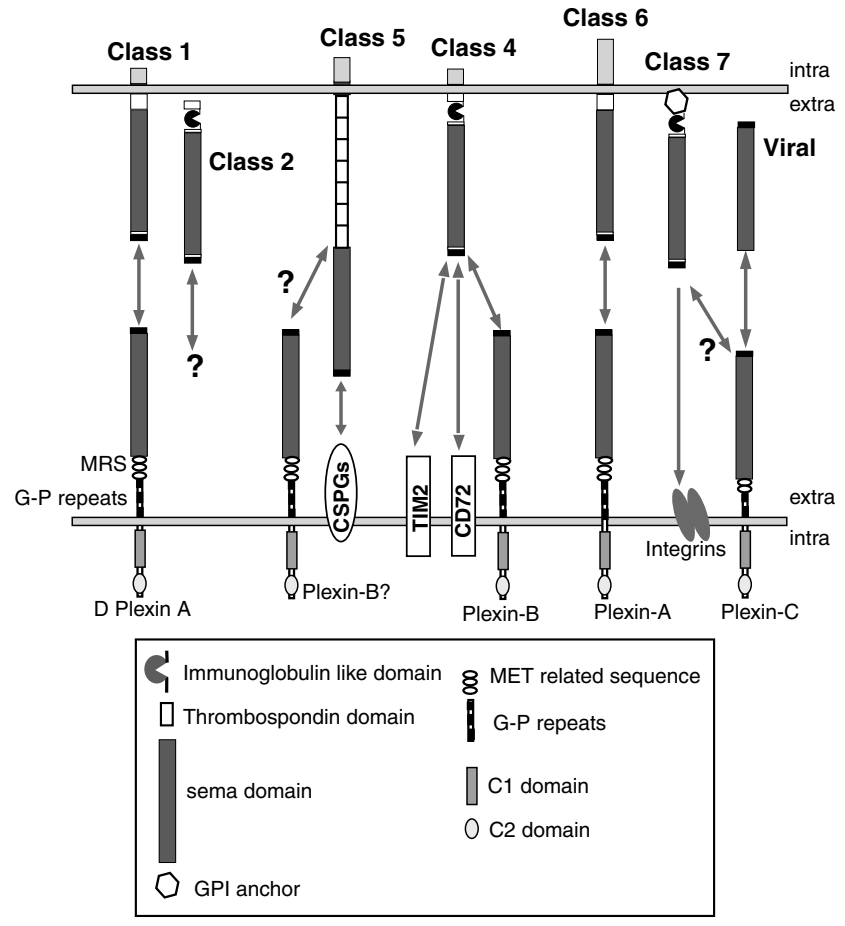

Figure 2 Membrane bound semaphorins and their receptors. Class 4 semaphorins have several known receptors. Sema4A receptor is a member of the T cell, immunoglobulin and mucin domain proteins (TIM) family, Tim- $2{ }^{64}$ Sema4D can bind plexin-B1 but its major receptor in the immune system is CD72. Other class 4 receptors are unknown. Class 5 semaphorins contains thrombospondin repeats in their extracellular domain. ${ }^{68}$ Sema5A binds to plexin-B3 but also chondroitin sulfate proteoglycans and heparan sulfate proteoglycans. Sema6D has recently been shown to bind plexin-A1. Sema7A is bound to the plasma membrane by a GPI anchor and could bind to plexin-C1 and integrins

neuropilins and are the signaling moiety of the receptor complex for secreted semaphorins. ${ }^{8}$ A cell adhesion molecule of the immunoglobulin $(\mathrm{Ig})$ superfamily, L1-CAM is also part of the receptor complex for Sema3A. ${ }^{21} \mathrm{~L} 1$ binds to neuropilin-1 and upon Sema3A binding, L1 and NP-1 are cointernalized through a clathrin-dependent mechanism mediated by $L 1 .{ }^{22}$ Interfering with this endocytosis blocks Sema3A inhibitory activity on axons. It remains to determine if additional cell adhesion molecules are involved in the signaling of other secreted semaphorins.

However, more recent data challenge this classical model. ${ }^{23}$ During development, Sema3E was found to repel migrating endothelial cells and control vascular patterning in vivo. Surprisingly, in this system Sema3E function is mediated by plexin-D1 and does not require neuropilin-1. Moreover, and in contradiction with earlier studies, Sema3E, but also Sema3B were found unable to bind to neuropilins. This result is hard to reconcile with previous findings that showed that Sema3B can act as antagonist for Sema3A on receptors containing neuropilin-1. ${ }^{24}$ It also suggests that Sema3B and other secreted semaphorins could signal through different receptors in different systems. Additional studies will be required to explain these discrepancies. Last, at least some Plexin-A are also receptors for class 6 transmembrane semaphorins (Toyofuku et al, ${ }^{25}$ see below).
SEMA3C was the first secreted semaphorin proposed to be involved in tumorigenesis. ${ }^{26} \mathrm{~A}$ screen for genes responsible for non-MDR (multidrug resistance) drug resistance in human ovarian cancer cell line (TyKnuR) and lung cancer cell line (Lu65/CDDP and MS-1/CDDP) identified SEMA3C as a gene overexpressed in these cells. Several glioma cell lines also express SEMA3C, neuropilins and plexin-As. ${ }^{27}$ The role of SEMA3C in these cancer cell lines is unclear. Sema3C binds neuropilins. As neuropilin-1 is implicated in angiogenesis (see below), SEMA3C could control directly or indirectly the vascularization of the tumors. Sema3C was also shown to promote the survival of cultured cerebellar granule cells ${ }^{28}$ and to attract cortical axons. ${ }^{13}$ Sema3C could thus have an autocrine/paracrine protective action on tumor cells or stimulate their migration. It will be important to determine if these cancer cell lines express SEMA3C receptors, such as neuropilin-2.

SEMA3E expression was also correlated positively with tumor progression in mouse mammary carcinoma ${ }^{29}$ and its mRNA (messenger ribonucleic acid) is overexpressed in metastatic human lung adenocarcinoma cell lines (HAL8Luc). ${ }^{30}$ However, sema3E function in tumorigenesis is also unclear. On dissociated neurons, Sema3E has either a repulsive action or a growth promoting one that is dosedependent. ${ }^{31,32}$ As mentioned before, this protein and its receptor plexin-D1 were recently shown to control angiogenesis during development ${ }^{23,33,34}$ and both could exert a similar function in tumors.

To date, most studies on semaphorins and cancer have focused on sema3B and sema3F. It is known that there is a frequent allele loss in chromosome region $3 p$ in many cancers (ovarian, breast gastric, renal, lung, etc.) and putative tumor suppressor genes were mapped to the 3p21.3 locus. Interestingly, both SEMA3B and SEMA3F were mapped to this region and thus suggested to play a direct role in tumorigenesis. ${ }^{35}$ Moreover, SEMA3B has been found at reduced levels or not expressed in lung cancer cells ${ }^{36,37}$ and is also often mutated, suggesting that SEMA3B may play a suppressive role in tumorigenesis. Last, SEMA3B promoter is hypermethylated in non-small-cell lung cancer cell lines or in tumor samples, and there is a significant loss of heterozygosity (LOH) in some tumors. ${ }^{36,38}$ SEMA3B transfection in lung cancer cell lines or application of exogenous soluble Sema3B ectodomain decrease colony formation and induces apoptosis. ${ }^{36}$ An antiproliferative activity of SEMA3B has been shown for breast cancer cell lines. ${ }^{39}$ In addition, in lung and breast cancer cell lines, SEMA3B effects are antagonized by the angiogenic factor vascular endothelial growth factor (VEGF) $165{ }^{39}$ suggesting that SEMA3B tumor suppressor activity involves VEGF signaling. Ovarian adenocarcinoma cells (HEY cells) also express 25 -fold less SEMA3B than in normal human ovary and have decreased tumorigenic properties in xenograft model. ${ }^{40}$ In addition, after stable transfection with SEMA3B expression constructs, their proliferation rate is decreased. Last, SEMA3B may also act as a mediator of p53-suppressor activity in glioblastoma cell lines. ${ }^{41}$ The emerging mode ${ }^{39}$ suggests that in premalignant cells, the activation of the p53 pathway leads to a decrease of SEMA3B expression and/or an overexpression of its antagonist VEGF, therefore allowing cancer cells to survive and 
proliferate. As HEY cells and lung cancer cells express neuropilins, it was proposed that in tumor cells, SEMA3B signals through these receptors and competes with neuropilin-mediated VEGF signaling. However, recent data suggest that this is not likely to occur as, at least in transfected cells, sema3B does not bind to neuropilins but to plexins (see above). The expression of plexins in most cancer cell lines will have to be carefully investigated.

SEMA3F expression is also downregulated in several cancer cell lines and tumors (see Roche et $a \beta^{35}$ for a review) but it is overexpressed in migrating lung cancer cells. ${ }^{42}$ SEMA3F inhibits the attachment and spreading of breast cancer cells (MCF7) apparently through interaction with neuropilin-1 and not neuropilin-2. ${ }^{43}$ SEMA3F is also able to antagonize VEGF action on these cells. Like Sema3A, Sema3F can inhibit angiogenesis and endothelial cell migration but through neuropilin-2 binding. ${ }^{4,45}$ SEMA3F overexpression in mouse fibrosarcoma or ovarian cancer cells block their proliferation. ${ }^{36,46}$ More recently it was shown that SEMA3F overexpression in highly metastatic melanoma cells (that only express neuropilin-2 and not neuropilin-1, VEGF-R1 or VEGFR-2) inhibits adhesion and migration but not proliferation. ${ }^{44}$ These SEMA3F-transfected melanoma cells injected into nude mice do not become metastatic. All these results suggest that SEMA3F could inhibit endothelial cell invasion and/or tumor cell migration.

Many recent studies have focused on the semaphorin receptors neuropilins that were found to play a pivotal role in angiogenesis. Binding experiments revealed that in addition to binding most class 3 semaphorins, neuropilin-1 is a receptor for VEGF-A (the VEGF165 but not the VEGF121 isoform), VEGF-B, VEGF-E and placental-derived growth factor-2 (see Bielenberg et al ${ }^{44}$ for references). Neuropilin-1 is expressed by tumor cells and endothelial cells, where it is a coreceptor for VEGFR-2 mediating VEGF function in angiogenesis. ${ }^{47,48}$ Interestingly, Sema3A binding to neuropilin-1 blocks the migration of endothelial cells. ${ }^{49}$ However, several class 3 semaphorins, including Sema3A are also expressed by endothelial cells ${ }^{50}$ and could have an autocrine action. Accordingly, Sema3A seems to exert a permissive role on angiogenesis by inhibiting integrins-mediated adhesion of endothelial cells allowing their deadhesion. ${ }^{50}$ The analysis of neuropilin-1 knockout mice has confirmed that neuropilin-1/ VEGF interaction is required for normal development of the vasculature. ${ }^{51}$ A soluble neuropilin-1 isoform was identified and found to have robust antitumor activity. ${ }^{52}$ Recently, two other soluble forms of neuropilin-1, sIIINRP1 and SIVNRP1, generated by alternative splicing, were discovered and both are expressed in human cancerous tissue. ${ }^{53}$ These soluble neuropilins also bind VEGF165 and sema3A. Likewise, neuropilin-2 is a receptor for VEGF165, VEGF145 and placental-derived growth factor- 2 . $^{54}$

The analysis of neuropilin expression in tumors and tumor cell lines showed that there is a differential expression of neuropilin-1 in two rat prostate carcinoma cell lines (AT2.1 and AT3.1), which have a differential motility in Boyden chambers. AT3.1 cells are more motile and express higher level of neuropilin-1 than AT2.1 cells. Upon transfection with neuropilin-1, AT2.1 cells increase their level of migration in Boyden chamber. They also form larger tumors when grafted in rats, possibly through an enhancement of angiogenesis involving VEGF signaling. Likewise, in glioblastoma, neuropilin-1 expression is increased in endothelial cells and neoplastic astrocytes. ${ }^{55} \mathrm{~A}$ possible role for Sema3A, in neuropilin-1 tumor activity has been recently investigated. ${ }^{56}$ This showed that VEGF binding to Neuropilin-1 is required for the survival of breast carcinoma cells. Those cells also express SEMA3A (and plexin-A1, a neuropilin-1 coreceptor) and lowering SEMA3A expression stimulates their migration. Likewise, SEMA3A expression is decreased in mesothelioma. ${ }^{57}$ In these cells, SEMA3A expression is transcriptionally induced by VEGF, through a p38 MAPK (microtubule associated protein kinase)-dependent pathway. As for SEMA3B, it is thought that a deregulation of the VEGF : SEMA3A ratio occurs in tumor cells, increasing their invasive potential. Overall, these experiments suggest that neuropilin-1 antagonists could be used to block tumor growth. These antagonists could be soluble neuropilin-1 recombinant proteins that could sequester VEGF, or Sema3A protein or peptides that could block tumor progression and endothelial cell migration. Some peptides able to mimick sema3A proapoptotic activity on cultured neurons have been identified, ${ }^{58}$ but their activity on cancer cell lines or tumors has not been tested so far. Other possible therapeutic agents are sIIINRP1 and SIVNRP1 that can block breast cancer cell migration. ${ }^{53}$

Although the majority of semaphorins are membranebound, their function in normal and pathological conditions remains largely unknown. Their receptors have also started to be identified and these studies suggest that they might be different in the nervous system and in other tissues, in particular in the immune system.

Class 4 semaphorins, the largest subclass with at least seven members, were shown to bind to type B plexins. In transfected cells, Sema4D binds to plexin-B1 leading to the small GTPases Rac1 and RhoA signaling pathway. ${ }^{59,60}$ Plexin-B1, -B2 and -B3 can also form receptor complexes with Met and Ron. ${ }^{61,62}$ It was shown that SEMA4D fixation on plexin-B1 can trigger invasive response of NIH3T3 cells in vitro by activating MET and Ron. ${ }^{61,62}$ Moreover, plexin-B1 is overexpressed, constitutively phosphorylated and associated with MET in liver, colon, gastric and pancreas carcinoma cell lines. ${ }^{62}$ Interestingly, plexin-B1 overexpression is sufficient to activate MET. Type B plexins could thus have an important role in the regulation of tumor invasion through their interaction with tyrosine kinase receptors such as MET and Ron. Accordingly, in the nervous system, plexin-B1 and plexin-B2 are highly expressed in regions of intense cell proliferation and migration (see Worzfeld et $a^{63}$ and $A C$ unpublished data).

Several class 4 semaphorins, such as Sema4A and Sema4D/CD100, are also involved in immune response. ${ }^{64}$ In the immune system, it was proposed that plexin-B1 is also a functional receptor for Sema4D, ${ }^{65}$ but most data show that Sema4D major receptor is CD72, a member of the C-type lectin family. ${ }^{64}$ In the immune system, Sema4A receptor is a member of the $\mathrm{T}$ cell, Ig and mucin domain proteins (TIM) family, Tim- $2,{ }^{64}$ and Tim-2 cytoplasmic region contains a consensus tyrosine phosphorylation site that is phosphorylated upon Sema4A binding. The receptors for other class 4 semaphorins are unknown. Despite their number and wide 
distribution, the expression and function of class 4 semaphorins in cancer is largely unknown. SEMA4D/CD100 is expressed on activated $B$ and $T$ lymphocytes and at high level in lymphoid and myeloid leukemia cells lines. ${ }^{66}$ SEMA4D is also expressed in T-cell non-Hodgkin's lymphoma and a subset of B-cell non-Hodgkin's lymphoma. B-cell chronic lymphocytic leukemia is characterized by the expansion of $\mathrm{CD} 5+\mathrm{B}$ lymphocytes and it was suggested that this could involve a signal delivered by $T$ cells to the malignant $B$ cells. Normal and malignant B cells express CD100/SEMA4D while its receptor plexin-B1 is expressed by activated T lymphocytes. Thus, CD100/plexin-B1 interaction could activate a survival or proliferation signal in CD5 + B cells that may favor the expansion of leukemic clones. ${ }^{65}$

In addition, it was shown that Sema4D promotes angiogenesis through Plexin-B1. Plexin-B1 is expressed in human umbilical vein endothelial cell (HUVEC) and porcin aortic endothelial (PAE) endothelial cells. Sema4D potently induced chemotaxis and tubulogenesis in PAE endothelial cells and enhanced blood vessel formation in mice. Interestingly, the angiogenic responses provoked by Sema4D do not seem to require MET activation. ${ }^{67}$ It is still unknown if Sema4D is implicated in tumor angiogenesis.

Class 5 semaphorins have four known members that all contains thrombospondin repeats in their extracellular domain. ${ }^{68}$ In the nervous system, Sema5A is expressed by oligodendrocytes and inhibits axonal growth. ${ }^{69}$ During development Sema5A is bifunctional, both attractive and repulsive, for some axons. ${ }^{70}$ It was shown that in transfected cells, Sema5A binds to plexin-B $3^{71}$ but the physiological relevance of this interaction is unclear. However, more recently, Sema5A activity on neurons was shown to require chondroitin sulfate proteoglycans and heparan sulfate proteoglycans. ${ }^{70}$

In Drosophila, neoplastic growth of the brain can be induced by inactivation of the lethal giant larvae l(2)glgene. Moreover, upon transplantation, l(2)gl tumor cells invade and metastasize to distant organs. ${ }^{68}$ A genetic screen for suppressors of the I(2)gl phenotype lead to the identification of Sema5C (tumor growth is blocked in the absence of sema5C). There are at least three class 5 semaphorins in human SEMA5A, SEMA5B and SEMA5D. ${ }^{68}$ Antibody staining showed that SEMA5A and SEMA5D are expressed in human melanoma cells (A2058) and SEMA5D in ovarian cancer cells. Likewise, SEMA5A is overexpressed in uterine leiomyomata ${ }^{72}$ and SEMA5B in human renal cell carcinoma. ${ }^{73}$

Class 6 semaphorins are closely related to insect class 1 transmembrane semaphorins. Recent studies in chick embryos have shown that Sema6D is a ligand for plexin-A1 and that their interaction is important for mediating the expansion of the cardiac primordium. ${ }^{74}$ However, at later stages of heart development plexin-A1 acts as a ligand and Sema6D as its receptor. ${ }^{25}$ Upon plexin-A1 binding Abl kinase is recruited to the cytoplasmic tail of Sema6D and activated, resulting in phosphorylation of enabled and dissociation from Sema6D. ${ }^{25}$ This is the first direct evidence of bi-directional signaling in this system and of a role for semaphorins as receptors. Other transmembrane semaphorins were also suggested to act as receptors for instance Sema1a and Sema4D, in Drosophila embryo and in immune cells respectively. ${ }^{75,76}$ Other class 6 semaphorins are able to inhibit axonal growth in dissociated neuronal culture ${ }^{77-79}$ but their receptors are still unknown. There are several isoforms of SEMA6A and SEMA6B generated by alternative splicing. ${ }^{80}$ One isoform of SEMA6B is downregulated in two human glioblastoma cell lines upon treatment with retinoids. This effect appears to require peroxisome proliferator activated receptors (PPARs ${ }^{81}$ ) that are transcription factors belonging to the nuclear hormone receptor superfamily and can associate with retinoic acid receptors. These data suggest that SEMA6B may play a role in tumor progression. Last, SEMA6A was mapped to $5 q 21-$ 22 , which is known to be deleted in certain forms of lung cancer. $^{82}$ SEMA7A, the only known class 7 semaphorin, is bound to the plasma membrane by a glycosyl phosphate inositol (GPI) anchor. ${ }^{83}$ SEMA7a (also known as CD108 in the immune system) is a close homologue of the alcelaphine herpes virus (AHV) semaphorin or AHVsema. Both were found to bind to plexin-C1. ${ }^{20,84}$ However, recent data suggest that in the nervous system integrins and in particular those containing the $\beta 1$ subunit, are functional receptors for Sema7A. ${ }^{85}$ A possible function of SEMA7A in cancer is unknown.

\section{The Slits and Robos}

The SLITS is the most recently discovered family of chemotropic factors. ${ }^{86}$ Slit (d-Slit) was first identified in Drosophila embryo. In fly, Slit is synthesized in the central nervous system by midline glia cells and in the absence of slit, longitudinal and commissural axons all converge and coalesce at the midline. ${ }^{86-89}$ More recent work has demonstrated that Slit is a chemorepulsive factor and a key regulator of midline crossing and axonal fasciculation. ${ }^{90,91}$ Slit homologues have since been found in virtually all vertebrate species. In mammals, three slit genes (slit1-slit3) have been cloned. ${ }^{86}$ All encode large ECM glycoproteins of about $200 \mathrm{kDa}$ (Figure 3), comprising, from their $\mathrm{N}$ terminus to their $\mathrm{C}$ terminus, a long stretch of four-leucine rich repeats, seven to nine EGF repeats, and a domain, named ALPS (agrin/laminin/ perlecan/slit), ${ }^{86,92}$ LNS $^{93}$ or laminin G (LG) module. ${ }^{94}$ Slits are proteolytically processed into a large $\mathrm{N}$-terminal and shorter C-terminal fragments in cell culture and in vivo. ${ }^{86}$ Slit cleavage fragments have different cell association characteristics, with the smaller $\mathrm{C}$-terminal fragment being more diffusible and the larger $\mathrm{N}$-terminal and full-length fragments being more tightly cell associated. Vertebrate Slits have also been shown to repel developing axons and migrating neurons. ${ }^{95}$ Slit proteins also repel migrating muscle precursors in fly embryos ${ }^{87}$ and mesodermal cells in zebrafish embryos. ${ }^{96}$ However, in rodents Slit2 can stimulate axonal elongation and branch formation of sensory axons from the dorsal root ganglia ${ }^{97}$ and attract migrating cells in Drosophila embryo. ${ }^{98}$

Roundabout (robo) proteins are the Slit receptors. ${ }^{87,99,100}$ Robo is an evolutionary conserved family of transmembrane receptors. ${ }^{89,90,101,102}$ Robo proteins define a small subgroup within the Ig superfamily (Figure 3 ) characterized by the presence of five Ig-like followed by three fibronectin type III (FNIII) repeats, a transmembrane portion and a long cytoplasmic tail containing robo-specific motifs. ${ }^{103}$ So far, three robo genes have been found in flies ${ }^{89,90,103}$ and 


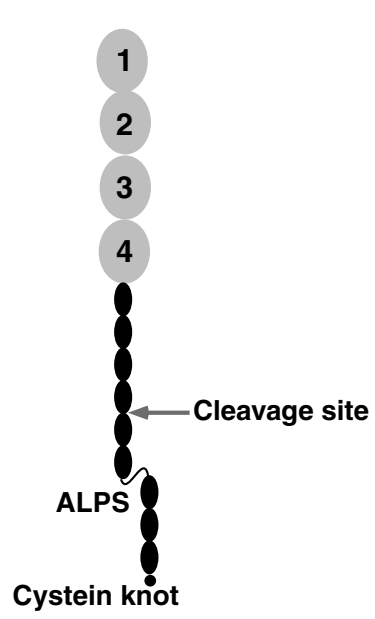

Slit

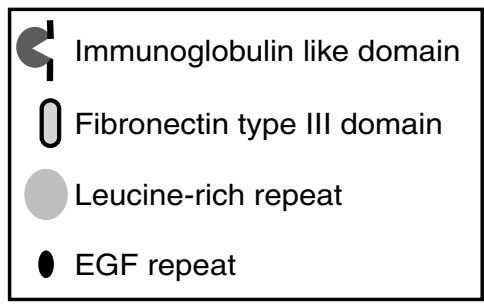

Figure 3 Slits and their receptors. Slit are large ECM glycoproteins comprising, from their $\mathrm{N}$ terminus to their $\mathrm{C}$ terminus, a long stretch of four leucine rich repeats, seven to nine EGF repeats, and an LG module. Slits are proteolytically processed into a large $\mathrm{N}$-terminal and shorter $\mathrm{C}$-terminal fragments. Roundabout (robo) are slit receptors and define a small subgroup within the immunoglobulin superfamily characterized by the presence of five Ig-like followed by three fibronectin type III (FNIII) repeats, a transmembrane portion and a long cytoplasmic tail containing robo-specific motifs

mammals. ${ }^{99,100}$ In mammals, CDO is another protein with $5 \mathrm{lg}$ 3FNIII, ${ }^{104}$ but its sequence is overall rather divergent from those of the three Robo receptors, suggesting that CDO probably does not belong to this family. Genetic and biochemical evidence shows that Slits are ligands of the robo1-robo3 receptors. ${ }^{89,90,103} \mathrm{~A}$ fourth putative robo gene, called magic roundabout or robo 4 was recently cloned and is only expressed by endothelial cells. ${ }^{105}$ However, it lacks some of the Ig domains and FNIII domains found in other robo proteins and its capacity to bind slits is still debated. ${ }^{106,107}$

The $\mathrm{N}$ terminal region of slits contains a stretch of four leucine-rich repeat domains (LRR) connected by disulfide bonds. These and the Ig domains of robo are important for signaling. Structure-function analysis in vertebrate and Drosophila revealed that the LRRs of slits are required and sufficient to mediate its repulsive activities in neurons. ${ }^{108-111}$ More recent studies have shown that in Drosophila all three Robo receptors compete for a single active binding site in the second LRR of Slit. ${ }^{108}$ Neither the FN3 domains nor Robo dimerization are required for slit binding. The major robo1-3 binding site of slit is in the second of the four LRRs, is evolutionary conserved and has a similar affinity for all robos.
However, slit affinity is higher when all LRRs are present, probably due to its dimerization. On the receptor side, several results suggest that the first two Ig domains of robos are required for slit binding. First, the genetic deletion of $\lg 1$ and Ig2 results in abnormal lung development. ${ }^{112}$ Second, antibodies against robo $\lg 1$ inhibit tumor growth in mice ${ }^{113}$ and neurite outgrowth in vitro. ${ }^{114}$ Third, robo1 $\lg 1-2$ are important for slit binding and function in vitro. ${ }^{115}$

Although slits and robos were only recently discovered there is mounting evidence suggesting that they are also involved in cancers. As mentioned previously, deletions and heterozygous loss on the short arm of chromosome 3 occur frequently in lung cancer. In lung tumor cell lines, homozygous deletions have been characterized in regions 3p12, 3p14 and 3p21, for instance in cell line U2020. ${ }^{116}$ Interestingly, ROBO1/ Dutt1 was mapped within the deletion and its promoter region is hypermethylated in primary lung, renal and breast tumors. So far, no somatic point mutation of ROBO1 (or of its ligands slits) was reported in tumors. These data suggest that ROBO1 may be a tumor suppressor gene. ${ }^{112} \mathrm{~A}$ targeted mutation of mouse robo1 was generated by deletion of exon 2, mimicking a deletion that naturally occurs in human small cell lung cancer cell line NIH-H219X, and resulted in the removal of Robo1 Ig1. In total, $63 \%$ of Robo1-/- homozygous die in the first $24 \mathrm{~h}$ because of respiratory failure due to abnormal lung development. A few homozygous survive up to 1 year and show bronchial hyperplasia, but no spontaneous tumor formation was detected. Recently, the tumor susceptibility of Robo1 heterozygous mice was analyzed. ${ }^{113}$ During their second year of life, Robo1 heterozygotes develop lymphoma and carcinomas, such as invasive lung carcinomas. In malignant tumor samples from Robo1 + /- mice, the expression of Robo1 is undetectable. Moreover, the study of the remaining allele showed that its promoter is hypermethylated. Overall, these studies support a role for Robo1 as a tumor suppressor gene, at least in the mouse.

Slit1, slit2 and slit3, the three known Robo ligands may also be involved in tumorigenesis. First, SLIT2 is expressed in many tumor cell lines ${ }^{117}$ such as human melanoma (A375), bladder squamous carcinoma (SCaBER), neuroblastoma (SK-N-SH), small cell lung cancer (NCl-H446), carcinoma of urinary bladder (T24), colon adenocarcinoma (LoVo), breast cancer (ZR-75-30), nasopharyngeal carcinoma (CNE), hepatocellular carcinoma (SMMC-7721), salivary gland carcinoma (Acc), rhabdomyosarcoma (A673) and primary tumors (melanoma, invasive breast carcinoma, colorectal carcinoma, etc.). Moreover, there appears to be a gradient of slit2 expression in primary tumors with highest concentration at the center.

SLIT1-3 expression is upregulated in prostate tumors, ${ }^{118}$ but decreased in breast and lung cancer cell lines and tumors and in gliomas. ${ }^{119,120}$ SLIT2 is mapped to 4 p15.2, a region associated with frequent LOH in many tumors. Accordingly, the inactivation of SLIT2 in tumors was shown to be epigenetic and caused by the hypermethylation of the promoter region. ${ }^{119,120}$ Very recently, a similar methylation of the promoter region of SLIT1 (1q23.3-q24) was detected in glioma tumor cell lines. ${ }^{121}$ This study also showed that SLIT3 (5q35-34) promoter is frequently hypermethylated in breast, lung, colorectal and glioma tumor cell lines and in primary 
breast tumors and gliomas. The observation that exogenous slit2 suppresses colony growth in breast cancer cell lines ${ }^{119}$ supports a possible tumor suppressor function of SLIT2. However, in tumors that express high level of SLIT2, its function is likely to be different. Many studies suggest that slit2 and its receptors have a potent angiogenic activity. Robo1 is expressed on HUVECs and their migration is increased by slit2 in Boyden Chamber assay. ${ }^{117}$ This chemotactic activity of slit2 is dose dependent, requires phosphatidylinositol-3 kinase (PI-3K) activation and can be inhibited by recombinant ectodomain (RoboN). In vivo, both RoboN or antibodies against the first Ig domain of Robo1 reduce tumor microvessel densities and tumor size while exogenous slit2 has a opposite proangiogenic activity. ${ }^{117}$ However, the expression of Robo proteins by endothelial cells in normal or metastatic tissue has not been reported yet and slit1/slit2 knockouts have an apparent normal vasculature. ${ }^{122}$ Therefore, the physiological relevance of these results is still unclear. Slits might also have other function in metastatic cells. Tumor cells often migrate to distant organs leading to secondary tumor formation and chemokines play a role in this process. Recently, slit2 was shown to be a potent inhibitor of stromal-derived factor (SDF)-1 induced leukocyte chemotaxis. ${ }^{123}$ This effect requires the interaction of CXCR4 with Robo1 that are both expressed by leukocytes. Breast cancer cells and human melanoma also express CXCR4, ROBO1 and ROBO2 and chemokines such as CXCL12 stimulate the migration of cancer cells. ${ }^{124}$ It has been shown that slit inhibits CXCL12/CXCR4-induced breast cancer cell (DU4475) chemotaxis, chemoinvasion and adhesion. Slit inhibits CXCL12-induced phosphorylation of the focal adhesion component FAK and RAFTK/Pyk2 and paxillin. It also inhibits CXCL12-induced Src kinase and PI3-kinase activities, p44/42 MAP kinase and activity of the matrix metalloproteinase MMP-2 and MMP-9 two proteolytic enzymes that play a role in tumor invasion through degradation of the extracellular matrix. ${ }^{124-126}$

\section{Netrins and their Receptors}

Although the existence of chemoattractive factors for growing axons was long suspected, ${ }^{127}$ the first direct experimental evidence for their existence was only obtained in 1986. ${ }^{128 .}$ Soon after, it was shown that in vertebrates, the ventral midline of the developing CNS, also called the floor plate, secretes some attractants for spinal cord commissural axons. ${ }^{129}$ The biochemical purification of this attractant led to the identification of netrin-1, a laminin related protein, ${ }^{130}$ whose function in regulating axon guidance at the midline of the nervous system is conserved in evolution. ${ }^{3}$ There are at least three netrin genes in mammals (netrin-1, netrin-3/ NTN2L and netrin-4 ${ }^{131-134}$ ). Netrin-1 can attract several classes of axons throughout the developing nervous system but also acts as a repulsive factor for some axons. ${ }^{135}$ In addition, netrin-1 controls neuronal migration in the developing and adult brain ${ }^{136}$ and the migration of pancreatic progenitors, ${ }^{137}$ neural crest cells, ${ }^{138}$ oligodendrocyte progenitors $^{139,140}$ and endothelial cells (see below). In the adult mouse brain, netrin-1 is expressed by some neurons and myelinating oligodendrocytes. ${ }^{141}$ In neurons, netrin-1 has several known receptors (Figure 4), Deleted in colorectal cancer (DCC), UNC5A, UNC5B, UNC5C and UNC5D ${ }^{142,143}$ and the adenosine receptor A2b.17, ${ }^{144,145}$ (see Patel and Van Vactor $^{146}$ for a review). In neurons, DCC was shown to mediate the attractive activity of netrin-1, in association with A2b. ${ }^{144,145}$ UNC5s seem required for netrin-1 repulsive activity, at least in vitro ${ }^{147-149}$ and this might also require interaction with DCC. ${ }^{140,150}$ However, in C. elegans and Drosophila embryo ${ }^{150}$ UNC5 could signal independently of DCC. The function of UNC5/netrin-1 interaction in vertebrate development in vivo is still unknown.

Netrin also binds to slit2 ${ }^{132}$ and to neogenin, a DCC-related receptor. ${ }^{151}$ (However, recent studies suggest that, at least in the nervous system, neogenin is a receptor for a GPI-linked protein named RGM (repulsive guidance protein ${ }^{152,153}$ ). Last, in fetal pancreatic epithelial cells, netrin function appears to be mediated by $\alpha 6 \beta 4$ integrins. ${ }^{137}$ All these receptors are
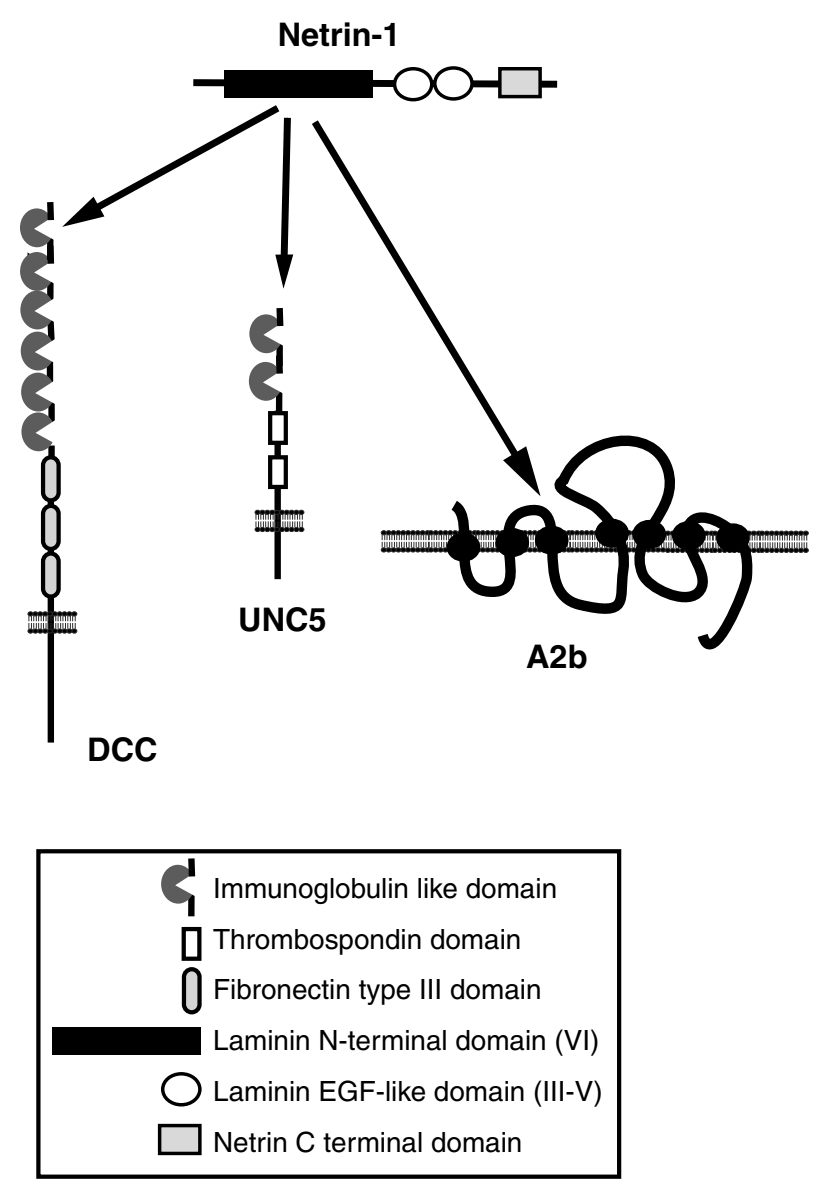

Figure 4 Netrin-1 and its receptors. Netrin-1 is a laminin related protein, containing a laminin $\mathrm{N}$-terminal domain, two laminin EGF-like domains and a netrin $C$ terminal domain. Several transmembrane netrin-1 receptors are known. Deleted in Colorectal Cancer (DCC) contains six Ig-like and three fibronectin type III (FNIII) repeats. UNC5A-UNC5D are composed of two Ig-like and two thrombospondin domains. Netrin also binds the adenosine receptor $A 2 b$, a seven membrane domain receptor 
expressed in many developing and adult tissues in normal condition (see Hinck ${ }^{4}$ for a review).

DCC was first characterized as a gene frequently deleted in colorectal cancers. ${ }^{154}$ DCC expression is also downregulated in prostate tumors, ${ }^{118}$ human gastric carcinoma ${ }^{155}$ endometrial cancer cell lines ${ }^{156}$ among others (for a recent review, see Arakawa ${ }^{157}$ ). DCC is at $18 q 21.2$, a locus of chromosome arm $18 q$ associated with frequent $\mathrm{LOH}$ in gastrointestinal cancers, suggesting that DCC is a tumor suppressor gene. Likewise, the expression of UNC5 genes is frequently downregulated in many primary tumors ${ }^{158}$ such as colorectal tumors, kidney tumors and lung tumors in association with significant $\mathrm{LOH}$.

One promising model suggests that UNC5 and DCC function in tumorigenesis is related to apoptosis. All these receptors were demonstrated to be dependence receptors (see Bredesen this issue): In the absence of their ligand netrin-1, their cytoplamic domain is cleaved by caspases and massive cell death occurs when they are overexpressed in cultured cells. Moreover, there is a death domain at the Cterminus end of UNC5 proteins. The exact mechanism by which DCC and UNC5 receptors trigger apoptosis is still largely unknown, but in the case of UNC5, a p53-dependent pathway may be involved (see Arakawa, this issue).

It was proposed that DCC and UNC5s act as tumor suppressors only when their ligand netrin-1 is not present. According to this model, the normal function of DCC and UNC5s could be to induce the death of tumor cells that have migrated away from their normal location, in territories where the ligand netrin-1 is absent. Therefore, in tumor cells, the lack of functional DCC or/and UNC5 would make the tumor cells resistant to apoptosis. ${ }^{159}$ Likewise, an excess or abnormal expression of netrin-1 would protect tumor cells still expressing DCC and UNC5 from death. This also suggests that netrin-1 function in normal tissues would be to interfere with DCC and UNC5s-dependent apoptosis. In support of this model, it has recently been shown that transgenic mice that overexpress netrin-1 in the intestine develop spontaneous intestinal tumors. ${ }^{160}$ However, an overexpression of netrin in or around human tumors has not been reported yet. As for semaphorins and slits, another possible function of netrins in cancer could be to regulate angiogenesis. It has just been shown that endothelial cells express UNC5B and $\mathrm{A} 2 \mathrm{~b}$ receptors and respond to netrin$1^{161,162}$ and vascular defects were detected in UNC5B knockouts. The exact mechanism of action of Netrin-1 in endothelial cells is still debated as it was shown to inhibit ${ }^{162}$ or stimulate HUVECs migration. ${ }^{161}$

\section{Conclusions}

Overall these data suggest that axon guidance molecules of the semaphorin, slit and netrin families and their receptors play important roles in tumorigenesis in many tissues and several possible functions and common properties are emerging (Table 1).

The development and growth of tumors require the simultaneous formation and sprouting of new blood vessels from pre-existing capillaries and veins. ${ }^{163}$ Surprisingly, many of these novel axon guidance molecules are angiogenic factors. Blood vessels that irrigate tumors were shown to express Robo1, neuropilin-1, plexins-B1 and-D1 and UNC5B. In the tumors, some axon guidance proteins such as netrin-1 and slit2 are upregulated and may directly increase angiogenesis upon binding their receptors on endothelial cells. Other axon guidance molecules, such as Sema3E, Sema3A and Sema3C, may act as inhibitors of angiogenesis in normal condition for instance by interfering with VEGF function. Their downregulation in some tumors may result in a stimulation of blood vessel development.

Many secreted axon guidance proteins such as netrin-1, Sema3B and Sema3A also play a role in apoptosis. In this case, their normal function could be to kill premalignant cells to block their migration and proliferation. The downregulation of their expression in tumors and/or the upregulation of the expression of their receptors could allow some malignant cells to survive, proliferate and migrate (Table 1).

Therefore, for therapeutic use it will be important to develop reagents that can either mimick the activity of secreted semaphorins such as Sema3A, or interfere with slit or netrin binding to their receptors. Such molecules have already been successfully used on developing neurons ${ }^{164,165}$ but still have to be tested on tumors. Moreover, the 3D-structure of several of these axon guidance proteins, in particular semaphorins and neuropilins, have been recently solved, which should help designing new molecules. ${ }^{11}$ Likewise, the signaling cascades activated by many axon guidance proteins have started to be identified in neurons ${ }^{2,8}$ and they may be similar in tumors. Other promising studies have shown that it is possible to switch the activity of netrin-1, slits and sema3A from attractive to repulsive, or vice versa, simply by modulating the intracytoplasmic concentration of molecules such as cyclic nucleotides or calcium. ${ }^{166}$ It will be important to determine if the same applies to tumor cells. As axon guidance molecules have multiple functions in different cells, it may be difficult to develop tumor specific therapeutic agents. Two examples are slit2 and Sema3A that in addition to their role in angiogenesis and neuronal development are very potent inhibitors of dendritic cell activation and of the immune response. ${ }^{167,168}$ However, it is not because tumor cells express some axon guidance proteins that their function in these cells is identical and it would probably be a mistake to directly apply models based on neurons to tumor cell biology. For instance, the semaphorin receptors appear to be distinct in the immune system and nervous system. In the developing heart, at least one semaphorin acts as a receptor. Robo proteins, plexins and neuropilins may also have homophilic properties. ${ }^{14,169}$ Last, many of these receptors, such as DCC and UNC5 ${ }^{149}$ DCC and Robo1, ${ }^{170}$ plexin-A4 and Robo2, ${ }^{171}$ have been shown to interact in growth cones.

At this time, this research field is at the beginning, and most studies on axon guidance proteins in tumors are still mostly descriptive and sometimes contradictory.

Knockout mice for slit1-slit3, robo1-robo3, neuropilins, plexin-A3, netrin-1, DCC, UNC5 are already available and many others in those families are being generated. Some important answers on the possible implication of axon guidance proteins in tumorigenesis will probably come from the analysis these knockout mice. 
Table 1 Possible function and expression of axon guidance molecules in cancer

\begin{tabular}{|c|c|c|c|}
\hline & Possible function in cancer & Expression in cancer & References \\
\hline SEMA3A & $\begin{array}{l}\text { May inhibit angiogenesis and migration of } \\
\text { endothelial cells (through neuropilin-1 binding) }\end{array}$ & $\begin{array}{l}\text { Downregulated in mesothelioma. } \\
\text { Expressed in breast carcinoma cells, lowering its } \\
\text { expression stimulates their migration. }\end{array}$ & $\begin{array}{l}15-18,50 \\
56-57\end{array}$ \\
\hline SEMA3B & $\begin{array}{l}\text { May play a suppressive role in tumorigenesis, } \\
\text { through neuropilins binding to compete with } \\
\text { neuropilin-mediated VEGF signaling }\end{array}$ & $\begin{array}{l}\text { Mapped to the 3p21.3 locus where there is a } \\
\text { frequent allele loss in many cancers. } \\
\text { Downregulated or mutated in lung cancer cells } \\
\text { and downregulated in ovarian adenocarcinoma } \\
\text { cells }\end{array}$ & $35-41$ \\
\hline SEMA3C & $\begin{array}{l}\text { Could control the vascularisation of the tumors } \\
\text { through Npn-1 binding. Promotes the survival of } \\
\text { cultured cerebellar granule cells }\end{array}$ & $\begin{array}{l}\text { Overexpressed in human ovarian cancer cell } \\
\text { lines, lung cancer cell lines and glioma cell lines }\end{array}$ & $\begin{array}{l}13,17-18 \\
26-28\end{array}$ \\
\hline SEMA3E & $\begin{array}{l}\text { Controls angiogenesis and vascular patterning } \\
\text { during development through plexin-D1 binding }\end{array}$ & $\begin{array}{l}\text { Overexpressed in mouse mammary carcinoma } \\
\text { metastatic cell lines and metastatic human lung } \\
\text { adenocarcinoma cell lines }\end{array}$ & $\begin{array}{l}18,23 \\
29-34\end{array}$ \\
\hline SEMA3F & $\begin{array}{l}\text { Inhibits angiogenesis, endothelial cell invasion } \\
\text { and/or tumor cell migration through Npn-2 } \\
\text { binding. Inhibits attachment and spreading of } \\
\text { breast cancer cells (MCF7 cells) through } \\
\text { interaction with Npn-1 }\end{array}$ & $\begin{array}{l}\text { Mapped to the 3p21.3 locus where there is a } \\
\text { frequent allele loss in many cancers. } \\
\text { Downregulated in several cancer cell lines and } \\
\text { tumors. Overexpressed in migrating lung cancer } \\
\text { cells }\end{array}$ & $\begin{array}{l}17,35-36 \\
42-46\end{array}$ \\
\hline Sema4D & $\begin{array}{l}\text { Trigger invasive response of NIH3T3 cells by } \\
\text { activating MET and Ron. Promotes } \\
\text { angiogenesis through plexin-B1 }\end{array}$ & $\begin{array}{l}\text { Highly expressed in lymphoid and myeloid } \\
\text { leukemia cells lines. Expressed in non-Hodgkin's } \\
\text { lymphoma and in malignant B cells }\end{array}$ & $\begin{array}{l}20,61-62 \\
65-67\end{array}$ \\
\hline SEMA5A & $\begin{array}{l}\text { Binds to plexin-B3, binds to CSPG and HSPG in } \\
\text { neurons }\end{array}$ & $\begin{array}{l}\text { Expressed in human melanoma cells (A2058), } \\
\text { over expressed in uterine leiomyomata }\end{array}$ & $68,70-2$ \\
\hline SEMA5B & & Expressed in human renal cell carcinoma & 68,73 \\
\hline Sema5C & Blocks tumor growth in Drosophila & & \\
\hline SEMA5D & & $\begin{array}{l}\text { Expressed in human melanoma cells and in } \\
\text { ovarian cancer cells }\end{array}$ & 68 \\
\hline SEMA6A & & Mapped to 5q21-22 deleted in lung cancer & 82 \\
\hline SEMA6B & & $\begin{array}{l}\text { Downregulated in human glioblastoma cell line } \\
\text { upon treatment with retinoids }\end{array}$ & 81 \\
\hline Sema6D & $\begin{array}{l}\text { Binds to plexin-A1 to regulate cardiac cell } \\
\text { proliferation and migration }\end{array}$ & & 25 \\
\hline Plexin-A1 & $\begin{array}{l}\text { Is a coreceptor for Neuropilin-1, binds to } \\
\text { Sema6D }\end{array}$ & $\begin{array}{l}\text { Expressed in breast carcinoma cells. Expressed } \\
\text { in glioma cell lines }\end{array}$ & $20,25,27,56$ \\
\hline $\begin{array}{l}\text { Plexin-A2 } \\
\text { Plexin-B1-3 }\end{array}$ & $\begin{array}{l}\text { Is a coreceptor of Neuropilins } \\
\text { Form receptor complexes with MET and Ron }\end{array}$ & Expressed in glioma cell lines & $\begin{array}{l}27 \\
61-2\end{array}$ \\
\hline Plexin-B1 & $\begin{array}{l}\text { Plexin B1 overexpression activates MET. Binds } \\
\text { to Sema4D. }\end{array}$ & $\begin{array}{l}\text { Overexpressed, constitutively phosphorylated } \\
\text { and associated with MET in liver, colon, gastric } \\
\text { and pancreas carcinoma cells. Expressed in } \\
\text { glioma cell lines }\end{array}$ & $20,27,62$ \\
\hline Neuropilin-1 & $\begin{array}{l}\text { Binds to class } 3 \text { semaphorins. Binds to VEGF-A } \\
\text { (VEGF165 but not VEGF 161), VEGF-B, VEGF- } \\
\text { E and PDGF-2 coreceptor with VEGFR-2 to } \\
\text { mediate VEGF function in angiogenesis }\end{array}$ & $\begin{array}{l}\text { Upregulated in endothelial cells and neoplastic } \\
\text { astrocytes in glioblastoma. } \\
\text { Expressed in breast carcinoma cells. } \\
\text { Expressed (as soluble forms sllINRP1 and } \\
\text { sIVNRP1) in human cancerous tissue (in glioma } \\
\text { cell lines and lung cancers) }\end{array}$ & $\begin{array}{l}44,47-9 \\
51-53 \\
55-56\end{array}$ \\
\hline Neuropilin-2 & $\begin{array}{l}\text { Binds to class } 3 \text { semaphorins receptor for } \\
\text { VEGF165, VEGF145 and PDGF2 }\end{array}$ & Expressed in glioma cell lines & $17,27,54$ \\
\hline SLIT1-3 & Binds to ROBO1-3 & $\begin{array}{l}\text { Upregulated in prostate tumors, downregulated } \\
\text { in breast and lung cancer cell line and tumors } \\
\text { and gliomas }\end{array}$ & $118-120$ \\
\hline SLIT1 & $\begin{array}{l}\text { Inhibits CXCL12/CXCR4-induced breast cancer } \\
\text { cells (DU4475) chemotaxis }\end{array}$ & & 124 \\
\hline SLIT2 & $\begin{array}{l}\text { Suppresses colony growth in breast cancer cell } \\
\text { lines. } \\
\text { Possible angiogenic activity. } \\
\text { Attracts HUVECs }\end{array}$ & $\begin{array}{l}\text { Expressed in human melanoma, bladder } \\
\text { squamous carcinoma, neuroblastoma, small-cell } \\
\text { lung cancer, carcinoma of urinary bladder, colon } \\
\text { adenocarcinoma (LoVo), breast cancer, } \\
\text { nasopharyngeal, hepatocellular and salivary } \\
\text { gland carcinoma, rhabdomyosarcoma and } \\
\text { primary tumors }\end{array}$ & 117,119 \\
\hline ROBO1 & $\begin{array}{l}\text { Binds to Slit1-3. } \\
\text { Reduces lymphoma and carcinoma } \\
\text { succeptibility. Possible angiogenic activity }\end{array}$ & $\begin{array}{l}\text { Mapped in a 3p region deleted in lung cancer cell } \\
\text { line (U2020) }\end{array}$ & 113,117 \\
\hline Netrin-1 & $\begin{array}{l}\text { Binds to DCC, UNC5A-D, neogenin, slit2, A2b } \\
\text { Overexpression induces intestinal cancer } \\
\text { Implicated in neuronal migration }\end{array}$ & & $\begin{array}{l}142-146 \\
160\end{array}$ \\
\hline DCC & Netrin-1 receptor, controls apoptosis & Downregulated in prostate tumors & 118 \\
\hline UNC5 & Netrin-1 receptor, controls apoptosis & $\begin{array}{l}\text { Downregulated in many primary cancer } \\
\text { (colorectal, kidney, and lung tumors) }\end{array}$ & 158 \\
\hline
\end{tabular}




\section{Acknowledgements}

This work is supported by the Association pour la recherche contre le Cancer (ARC), the Fondation pour la Recherche sur le Cerveau (FRC), the Institut National de la Santé et de la Recherche Médicale (INSERM) and the Assistance Publique et Hôpitaux de Paris (AP-HP).

\section{References}

1. Pfrieger FW and Barres BA (1995) What the fly's glia tell the fly's brain. Cell 83: $671-674$

2. Dickson BJ (2002) Molecular mechanisms of axon guidance. Science 298: 1959-1964

3. Goodman CS (1994) The likeness of being: phylogenetically conserved molecular mechanisms of growth cone guidance. Cell 78: 353-356

4. Hinck L (2004) The versatile roles of 'axon guidance' cues in tissue morphogenesis. Dev. Cell 7: 783-793

5. Surawska H, Ma PC and Salgia R (2004) The role of ephrins and Eph receptors in cancer. Cytokine Growth Factor Rev. 15: 419-433

6. Kolodkin AL, Matthes DJ and Goodman CS (1993) The semaphorin genes encode a family of transmembrane and secreted growth cone guidance molecules. Cell 75: 1389-1399

7. Luo Y, Shepherd I, Li J, Renzi MJ, Chang S and Raper JA (1995) A family of molecules related to collapsin in the embryonic chick nervous system. Neuron 14: $1131-1140$

8. Fiore R and Puschel AW (2003) The function of semaphorins during nervous system development. Front. Biosci. 8: s484-s499

9. Semaphorin Nomenclature Committee (1999) Unified nomenclature for the semaphorins/collapsins. Cell 97: 551-552

10. Winberg ML, Noordermeer JN, Tamagnone L, Comoglio PM, Spriggs MK, Tessier-Lavigne M and Goodman CS (1998) Plexin A is a neuronal semaphorin receptor that controls axon guidance. Cell 95: 903-916

11. Gherardi E, Love CA, Esnouf RM and Jones EY (2004) The sema domain. Curr. Opin. Struct. Biol. 14: 669-678

12. de Castro F, Hu L, Drabkin H, Sotelo C and Chedotal A (1999) Chemoattraction and chemorepulsion of olfactory bulb axons by different secreted semaphorins. J. Neurosci. 19: 4428-4436

13. Bagnard D, Lohrum M, Uziel D, Puschel AW and Bolz J (1998) Semaphorins act as attractive and repulsive guidance signals during the development of cortical projections. Development 125: 5043-5053

14. Polleux F, Morrow T and Ghosh A (2000) Semaphorin $3 A$ is a chemoattractant for cortical apical dendrites. Nature 404: 567-573

15. He $Z$ and Tessier-Lavigne M (1997) Neuropilin is a receptor for the axonal chemorepellent Semaphorin III. Cell 90: 739-751

16. Kolodkin AL, Levengood DV, Rowe EG, Tai YT, Giger RJ and Ginty DD (1997) Neuropilin is a semaphorin III receptor. Cell 90: 753-762

17. Chen H, Chedotal A, He Z, Goodman CS and Tessier-Lavigne M (1997) Neuropilin-2, a novel member of the neuropilin family, is a high affinity receptor for the semaphorins Sema E and Sema IV but not Sema III. Neuron. 19: $547-559$

18. Feiner L, Koppel AM, Kobayashi H and Raper JA (1997) Secreted chick semaphorins bind recombinant neuropilin with similar affinities but bind different subsets of neurons in situ. Neuron 19: 539-545

19. Cai H and Reed RR (1999) Cloning and characterization of neuropilin-1interacting protein: a PSD-95/D/g/ZO-1 domain-containing protein that interacts with the cytoplasmic domain of neuropilin-1. J. Neurosci. 19: 6519-6527

20. Tamagnone L, Artigiani S, Chen H, He Z, Ming Gl, Song H, Chedotal A Winberg ML, Goodman CS, Poo M, Tessier-Lavigne M and Comoglio PM (1999) Plexins are a large family of receptors for transmembrane, secreted, and GPI-anchored semaphorins in vertebrates. Cell 99: 71-80

21. Castellani V, Chedotal $A$, Schachner M, Faivre-Sarrailh $C$ and Rougon $G$ (2000) Analysis of the L1-deficient mouse phenotype reveals cross-talk between Sema3A and L1 signaling pathways in axonal guidance. Neuron 27 237-249

22. Castellani V, Falk J and Rougon G (2004) Semaphorin3A-induced receptor endocytosis during axon guidance responses is mediated by L1 CAM. Mol. Cell Neurosci. 26: 89-100
23. Gu C, Yoshida Y, Livet J, Reimert DV, Mann F, Merte J, Henderson CE, Jessell TM, Kolodkin AL and Ginty DD (2004) Semaphorin 3E and Plexin-D1 control vascular pattern independently of neuropilins. Science 307: 265-268

24. Takahashi T, Nakamura F, Jin Z, Kalb RG and Strittmatter SM (1998) Semaphorins A and $E$ act as antagonists of neuropilin-1 and agonists of neuropilin-2 receptors. Nat. Neurosci. 1: 487-493

25. Toyofuku T, Zhang H, Kumanogoh A, Takegahara N, Suto F, Kamei J, Aoki K, Yabuki M, Hori M, Fujisawa H and Kikutani H (2004) Dual roles of Sema6D in cardiac morphogenesis through region-specific association of its receptor, Plexin-A1, with off-track and vascular endothelial growth factor receptor type 2. Genes Dev. 18: 435-447

26. Yamada T, Endo R, Gotoh M and Hirohashi S (1997) Identification of semaphorin $E$ as a non-MDR drug resistance gene of human cancers. Proc. Natl. Acad. Sci. USA 94: 14713-14718

27. Rieger J, Wick $W$ and Weller $M(2003)$ Human malignant glioma cells express semaphorins and their receptors, neuropilins and plexins. Glia 42: 379-389

28. Moreno-Flores MT, Martin-Aparicio E, Martin-Bermejo MJ, Agudo M, McMahon S, Avila J, Diaz-Nido J and Wandosell F (2003) Semaphorin 3C preserves survival and induces neuritogenesis of cerebellar granule neurons in culture. J. Neurochem. 87: 879-890

29. Christensen CR, Klingelhofer J, Tarabykina S, Hulgaard EF, Kramerov D and Lukanidin E (1998) Transcription of a novel mouse semaphorin gene, MsemaH, correlates with the metastatic ability of mouse tumor cell lines. Cancer Res. 58: 1238-1244

30. Martin-Satue M and Blanco J (1999) Identification of semaphorin E gene expression in metastatic human lung adenocarcinoma cells by mRNA differential display. J. Surg. Oncol. 72: 18-23

31. Miyazaki N, Furuyama T, Amasaki M, Sugimoto H, Sakai T, Takeda N, Kubo T and Inagaki S (1999) Mouse semaphorin H inhibits neurite outgrowth from sensory neurons. Neurosci. Res. 33: 269-274

32. Sakai T, Furuyama T, Ohoka Y, Miyazaki N, Fujioka S, Sugimoto H, Amasaki M, Hattori S, Matsuya T and Inagaki S (1999) Mouse semaphorin H induces PC12 cell neurite outgrowth activating Ras-mitogen-activated protein kinase signaling pathway via $\mathrm{Ca}(2+)$ influx. J. Biol. Chem. 274: 29666-29671

33. Gitler AD, Lu MM and Epstein JA (2004) PlexinD1 and semaphorin signaling are required in endothelial cells for cardiovascular development. Dev. Cell 7: $107-116$

34. Torres-Vazquez J, Gitler AD, Fraser SD, Berk JD, Van NP, Fishman MC, Childs S, Epstein JA and Weinstein BM (2004) Semaphorin-plexin signaling guides patterning of the developing vasculature. Dev. Cell 7: 117-123

35. Roche J, Drabkin H and Brambilla E (2002) Neuropilin and its ligands in normal lung and cancer. Adv. Exp. Med. Biol. 515: 103-114

36. Tomizawa Y, Sekido Y, Kondo M, Gao B, Yokota J, Roche J, Drabkin H, Lerman MI, Gazdar AF and Minna JD (2001) Inhibition of lung cancer cell growth and induction of apoptosis after reexpression of 3p21.3 candidate tumor suppressor gene SEMA3B. Proc. Natl. Acad. Sci. USA 98: 1395413959

37. de Lange R, Dimoudis N and Weidle UH (2003) Identification of genes associated with enhanced metastasis of a large cell lung carcinoma cell line. Anticancer Res. 23: 187-194

38. Kuroki T, Trapasso F, Yendamuri S, Matsuyama A, Alder H, Williams NN, Kaiser LR and Croce CM (2003) Allelic loss on chromosome 3p21.3 and promoter hypermethylation of semaphorin $3 \mathrm{~B}$ in non-small cell lung cancer. Cancer Res. 63: 3352-3355

39. Castro-Rivera E, Ran S, Thorpe P and Minna JD (2004) Semaphorin 3B (SEMA3B) induces apoptosis in lung and breast cancer, whereas VEGF165 antagonizes this effect. Proc. Natl. Acad. Sci. USA 101: 11432-11437

40. Tse C, Xiang RH, Bracht T and Naylor SL (2002) Human Semaphorin 3B (SEMA3B) located at chromosome 3p21.3 suppresses tumor formation in an adenocarcinoma cell line. Cancer Res. 62: 542-546

41. Ochi K, Mori T, Toyama Y, Nakamura Y and Arakawa H (2002) Identification of semaphorin3B as a direct target of p53. Neoplasia 4: 82-87

42. Lantuejoul S, Constantin B, Drabkin H, Brambilla C, Roche J and Brambilla E (2003) Expression of VEGF, semaphorin SEMA3F, and their common receptors neuropilins NP1 and NP2 in preinvasive bronchial lesions, lung tumours, and cell lines. J. Pathol. 200: 336-347

43. Nasarre P, Constantin B, Rouhaud L, Harnois T, Raymond G, Drabkin HA, Bourmeyster N and Roche J (2003) Semaphorin SEMA3F and VEGF have opposing effects on cell attachment and spreading. Neoplasia 5: 83-92 
44. Bielenberg DR, Hida Y, Shimizu A, Kaipainen A, Kreuter M, Kim CC and Klagsbrun M (2004) Semaphorin $3 F$, a chemorepulsant for endothelial cells, induces a poorly vascularized, encapsulated, nonmetastatic tumor phenotype. J. Clin. Invest. 114: 1260-1271

45. Kessler O, Shraga-Heled N, Lange T, Gutmann-Raviv N, Sabo E, Baruch L, Machluf M and Neufeld G (2004) Semaphorin-3F is an inhibitor of tumor angiogenesis. Cancer Res. 64: 1008-1015

46. Xiang R, Davalos AR, Hensel CH, Zhou XJ, Tse C and Naylor SL (2002) Semaphorin $3 F$ gene from human 3p21.3 suppresses tumor formation in nude mice. Cancer Res. 62: 2637-2643

47. Soker S, Takashima S, Miao HQ, Neufeld G and Klagsbrun M (1998) Neuropilin-1 is expressed by endothelial and tumor cells as an isoformspecific receptor for vascular endothelial growth factor. Cell 92: 735-745

48. Soker S, Miao HQ, Nomi M, Takashima S and Klagsbrun M (2002) VEGF165 mediates formation of complexes containing VEGFR-2 and neuropilin-1 that enhance VEGF165-receptor binding. J. Cell. Biochem. 85: 357-368

49. Miao HQ, Soker S, Feiner L, Alonso JL, Raper JA and Klagsbrun M (1999) Neuropilin-1 mediates collapsin-1/semaphorin III inhibition of endothelial cell motility: functional competition of collapsin-1 and vascular endothelial growth factor-165. J. Cell. Biol. 146: 233-242

50. Serini G, Valdembri D, Zanivan S, Morterra G, Burkhardt C, Caccavari F, Zammataro L, Primo L, Tamagnone L, Logan M, Tessier-Lavigne M, Taniguchi M, Puschel AW and Bussolino F (2003) Class 3 semaphorins control vascular morphogenesis by inhibiting integrin function. Nature 424 : 391-397

51. Gu C, Rodriguez ER, Reimert DV, Shu T, Fritzsch B, Richards LJ, Kolodkin AL and Ginty DD (2003) Neuropilin-1 conveys semaphorin and VEGF signaling during neural and cardiovascular development. Dev. Cell 5: 45-57

52. Gagnon ML, Bielenberg DR, Gechtman Z, Miao HQ, Takashima S, Soker S and Klagsbrun M (2000) Identification of a natural soluble neuropilin-1 that binds vascular endothelial growth factor: in vivo expression and antitumor activity. Proc. Natl. Acad. Sci. USA 97: 2573-2578

53. Cackowski FC, Xu L, Hu B and Cheng SY (2004) Identification of two novel alternatively spliced Neuropilin-1 isoforms. Genomics 84: 82-94

54. Gluzman-Poltorak Z, Cohen T, Herzog Y and Neufeld G (2000) Neuropilin-2 is a receptor for the vascular endothelial growth factor (VEGF) forms VEGF-145 and VEGF-165. J. Biol. Chem. 275: 29922

55. Broholm $\mathrm{H}$ and Laursen $\mathrm{H}$ (2004) Vascular endothelial growth factor (VEGF) receptor neuropilin-1's distribution in astrocytic tumors. Apmis 112: 257-263

56. Bachelder RE, Lipscomb EA, Lin X, Wendt MA, Chadborn NH, Eickholt BJ and Mercurio AM (2003) Competing autocrine pathways involving alternative neuropilin-1 ligands regulate chemotaxis of carcinoma cells. Cancer Res. 63: 5230-5233

57. Catalano A, Caprari P, Rodilossi S, Betta P, Castellucci M, Casazza A, Tamagnone $L$ and Procopio A (2004) Cross-talk between vascular endothelial growth factor and semaphorin-3A pathway in the regulation of normal and malignant mesothelial cell proliferation. FASEB J. 18: 358-360

58. Shirvan A, Shina R, Ziv I, Melamed E and Barzilai A (2000) Induction of neuronal apoptosis by Semaphorin3A-derived peptide. Brain Res. Mol. Brain Res. 83: 81-93

59. Vikis HG, Li W, He Z and Guan KL (2000) The semaphorin receptor plexin-B1 specifically interacts with active Rac in a ligand-dependent manner. Proc. Natl. Acad. Sci. USA 97: 12457-12462

60. Swiercz JM, Kuner R, Behrens J and Offermanns S (2002) Plexin-B1 directly interacts with PDZ-RhoGEF/LARG to regulate RhoA and growth cone morphology. Neuron 35: 51-63

61. Giordano S, Corso S, Conrotto P, Artigiani S, Gilestro G, Barberis D, Tamagnone $L$ and Comoglio PM (2002) The semaphorin 4D receptor controls invasive growth by coupling with Met. Nat. Cell Biol. 4: 720-724

62. Conrotto P, Corso S, Gamberini S, Comoglio PM and Giordano S (2004) Interplay between scatter factor receptors and B plexins controls invasive growth. Oncogene 23: 5131-5137

63. Worzfeld T, Puschel AW, Offermanns S and Kuner R (2004) Plexin-B family members demonstrate non-redundant expression patterns in the developing mouse nervous system: an anatomical basis for morphogenetic effects of Sema4D during development. Eur. J. Neurosci. 19: 2622-2632

64. Kumanogoh A and Kikutani $H$ (2003) Immune semaphorins: a new area of semaphorin research. J. Cell Sci. 116: 3463-3470
65. Granziero L, Circosta P, Scielzo C, Frisaldi E, Stella S, Geuna M, Giordano S, Ghia P and Caligaris-Cappio F (2003) CD100/Plexin-B1 interactions sustain proliferation and survival of normal and leukemic CD5+ B lymphocytes. Blood 101: 1962-1969

66. Dorfman DM, Shahsafaei A, Nadler LM and Freeman GJ (1998) The leukocyte semaphorin CD100 is expressed in most T-cell, but few B-cell, nonHodgkin's lymphomas. Am. J. Pathol. 153: 255-262

67. Basile JR, Barac A, Zhu T, Guan KL and Gutkind JS (2004) Class IV semaphorins promote angiogenesis by stimulating Rho-initiated pathways through plexin-B. Cancer Res. 64: 5212-5224

68. Woodhouse EC, Fisher A, Bandle RW, Bryant-Greenwood B, Charboneau L, Petricoin III EF and Liotta LA (2003) Drosophila screening model for metastasis: semaphorin $5 \mathrm{c}$ is required for $\mathrm{I}(2) \mathrm{gl}$ cancer phenotype. Proc. Natl. Acad. Sci. USA 100: 11463-11468

69. Goldberg JL, Vargas ME, Wang JT, Mandemakers W, Oster SF, Sretavan DW and Barres BA (2004) An oligodendrocyte lineage-specific semaphorin, Sema5A, inhibits axon growth by retinal ganglion cells. J. Neurosci. 24: 4989-4999

70. Kantor DB, Chivatakarn O, Peer KL, Oster SF, Inatani M, Hansen MJ, Flanagan JG, Yamaguchi Y, Sretavan DW, Giger RJ and Kolodkin AL (2004) Semaphorin $5 \mathrm{~A}$ is a bifunctional axon guidance cue regulated by heparan and chondroitin sulfate proteoglycans. Neuron 44: 961-975

71. Artigiani S, Conrotto P, Fazzari P, Gilestro GF, Barberis D, Giordano S, Comoglio PM and Tamagnone $L$ (2004) Plexin-B3 is a functional receptor for semaphorin 5A. EMBO Rep. 5: 710-714

72. Tsibris JC, Segars J, Coppola D, Mane S, Wilbanks GD, O'Brien WF and Spellacy WN (2002) Insights from gene arrays on the development and growth regulation of uterine leiomyomata. Fertil. Steril. 78: 114-121

73. Stassar MJ, Devitt G, Brosius M, Rinnab L, Prang J, Schradin T, Simon J, Petersen S, Kopp-Schneider A and Zoller M (2001) Identification of human renal cell carcinoma associated genes by suppression subtractive hybridization. Br. J. Cancer 85: 1372-1382

74. Toyofuku T, Zhang H, Kumanogoh A, Takegahara N, Yabuki M, Harada K, Hori M and Kikutani H (2004) Guidance of myocardial patterning in cardiac development by Sema6D reverse signalling. Nat. Cell Biol. 6: 1204-1211

75. Elhabazi A, Lang V, Herold C, Freeman GJ, Bensussan A, Boumsell L and Bismuth $G$ (1997) The human semaphorin-like leukocyte cell surface molecule CD100 associates with a serine kinase activity. J. Biol. Chem. 272: 23515-23520

76. Godenschwege TA, Hu H, Shan-Crofts X, Goodman CS and Murphey RK (2002) Bi-directional signaling by Semaphorin 1a during central synapse formation in Drosophila. Nat. Neurosci. 5: 1294-1301

77. Kikuchi K, Chedotal A, Hanafusa H, Ujimasa Y, de Castro F, Goodman CS and Kimura T (1999) Cloning and characterization of a novel class VI semaphorin, semaphorin Y. Mol. Cell. Neurosci. 13: 9-23

78. Xu XM, Fisher DA, Zhou L, White FA, Ng S, Snider WD and Luo Y (2000) The transmembrane protein semaphorin $6 \mathrm{~A}$ repels embryonic sympathetic axons. J. Neurosci. 20: 2638-2648

79. Qu X, Wei H, Zhai Y, Que H, Chen Q, Tang F, Wu Y, Xing G, Zhu Y, Liu S, Fan $\mathrm{M}$ and $\mathrm{He} F$ (2002) Identification, characterization, and functional study of the two novel human members of the semaphorin gene family. J. Biol. Chem. 277: 35574-35585

80. Correa RG, Sasahara RM, Bengtson MH, Katayama ML, Salim AC, Brentani MM, Sogayar MC, de Souza SJ and Simpson AJ (2001) Human semaphorin 6B [(HSA)SEMA6B], a novel human class 6 semaphorin gene: alternative splicing and all-trans-retinoic acid-dependent downregulation in glioblastoma cell lines. Genomics 73: 343-348

81. Collet $\mathrm{P}$, Domenjoud L, Devignes MD, Murad $\mathrm{H}$, Schohn $\mathrm{H}$ and Dauca $\mathrm{M}$ (2004) The human semaphorin 6B gene is down regulated by PPARs. Genomics 83: 1141-1150

82. Klostermann A, Lutz B, Gertler F and Behl C (2000) The orthologous human and murine semaphorin $6 \mathrm{~A}-1$ proteins (SEMA6A-1/Sema6A-1) bind to the enabled/vasodilator-stimulated phosphoprotein-like protein (EVL) via a novel carboxyl-terminal zyxin-like domain. J. Biol. Chem. 275: 39647-39653

83. Xu X, Ng S, Wu ZL, Nguyen D, Homburger S, Seidel-Dugan C, Ebens A and Luo Y (1998) Human semaphorin K1 is glycosylphosphatidylinositol-linked and defines a new subfamily of viral-related semaphorins. J. Biol. Chem. 273 $22428-22434$ 
84. Comeau MR, Johnson R, DuBose RF, Petersen M, Gearing P, VandenBos T, Park L, Farrah T, Buller RM, Cohen JI, Strockbine LD, Rauch C and Spriggs MK (1998) A poxvirus-encoded semaphorin induces cytokine production from monocytes and binds to a novel cellular semaphorin receptor, VESPR. Immunity 8: 473-482

85. Pasterkamp RJ and Kolodkin AL (2003) Semaphorin junction: making tracks toward neural connectivity. Curr. Opin. Neurobiol. 13: 79-89

86. Brose $\mathrm{K}$ and Tessier-Lavigne $\mathrm{M}(2000)$ Slit proteins: key regulators of axon guidance, axonal branching, and cell migration. Curr. Opin. Neurobiol. 10: 95-102

87. Kidd T, Bland KS and Goodman CS (1999) Slit is the midline repellent for the robo receptor in Drosophila. Cell 96: 785-794

88. Rajagopalan S, Nicolas E, Vivancos V, Berger J and Dickson BJ (2000) Crossing the midline: roles and regulation of Robo receptors. Neuron 28: 767-777

89. Simpson JH, Kidd T, Bland KS and Goodman CS (2000) Short-range and long-range guidance by slit and its Robo receptors. Robo and Robo2 play distinct roles in midline guidance. Neuron 28: 753-766

90. Rajagopalan S, Vivancos V, Nicolas E and Dickson BJ (2000) Selecting a longitudinal pathway: Robo receptors specify the lateral position of axons in the Drosophila CNS. Cell 103: 1033-1045

91. Simpson JH, Bland KS, Fetter RD and Goodman CS (2000) Short-range and long-range guidance by Slit and its Robo receptors: a combinatorial code of Robo receptors controls lateral position. Cell 103: 1019-1032

92. Rothberg JM and Artavanis-Tsakonas S (1992) Modularity of the slit protein. Characterization of a conserved carboxy-terminal sequence in secreted proteins and a motif implicated in extracellular protein interactions. J. Mol. Biol. 227: 367-370

93. Rudenko G, Nguyen T, Chelliah Y, Sudhof TC and Deisenhofer J (1999) The structure of the ligand-binding domain of neurexin lbeta: regulation of LNS domain function by alternative splicing. Cell 99: 93-101

94. Hohenester E, Tisi D, Talts JF and Timpl R (1999) The crystal structure of a laminin G-like module reveals the molecular basis of alpha-dystroglycan binding to laminins, perlecan, and agrin. Mol. Cell 4: 783-792

95. Nguyen-Ba-Charvet KT and Chedotal A (2002) Role of Slit proteins in the vertebrate brain. J. Physiol. Paris 96: 91-98

96. Yeo SY, Little MH, Yamada T, Miyashita T, Halloran MC, Kuwada JY, Huh TL and Okamoto $H$ (2001) Overexpression of a slit homologue impairs convergent extension of the mesoderm and causes cyclopia in embryonic zebrafish. Dev. Biol. 230: 1-17

97. Wang KH, Brose K, Arnott D, Kidd T, Goodman CS, Henzel W and TessierLavigne M (1999) Biochemical purification of a mammalian slit protein as a positive regulator of sensory axon elongation and branching. Cell 96: 771-784

98. Kramer SG, Kidd T, Simpson JH and Goodman CS (2001) Switching repulsion to attraction: changing responses to slit during transition in mesoderm migration. Science 292: 737-740

99. Brose K, Bland KS, Wang KH, Arnott D, Henzel W, Goodman CS, TessierLavigne M and Kidd T (1999) Slit proteins bind Robo receptors and have an evolutionarily conserved role in repulsive axon guidance. Cell 96: 795-806

100. Li HS, Chen JH, Wu W, Fagaly T, Zhou L, Yuan W, Dupuis S, Jiang ZH, Nash W, Gick C, Ornitz DM, Wu JY and Rao Y (1999) Vertebrate slit, a secreted ligand for the transmembrane protein roundabout, is a repellent for olfactory bulb axons. Cell 96: 807-818

101. Challa AK, Beattie CE and Seeger MA (2001) Identification and characterization of roundabout orthologs in zebrafish. Mech. Dev. 101: 249-253

102. Zallen JA, Yi BA and Bargmann $\mathrm{Cl}$ (1998) The conserved immunoglobulin superfamily member $S A X-3 /$ Robo directs multiple aspects of axon guidance in C.elegans. Cell 92: 217-227

103. Kidd T, Brose K, Mitchell KJ, Fetter RD, Tessier-Lavigne M, Goodman CS and Tear G (1998) Roundabout controls axon crossing of the CNS midline and defines a novel subfamily of evolutionarily conserved guidance receptors. Cell 92: 205-215

104. Kang JS, Mulieri PJ, Miller C, Sassoon DA and Krauss RS (1998) CDO, a robo-related cell surface protein that mediates myogenic differentiation. J. Cell Biol. 143: 403-413

105. Huminiecki L, Gorn M, Suchting S, Poulsom R and Bicknell R (2002) Magic roundabout is a new member of the roundabout receptor family that is endothelial specific and expressed at sites of active angiogenesis. Genomics 79: $547-552$
106. Park KW, Morrison CM, Sorensen LK, Jones CA, Rao Y, Chien CB, Wu JY, Urness LD and Li DY (2003) Robo4 is a vascular-specific receptor that inhibits endothelial migration. Dev. Biol. 261: 251-267

107. Suchting S, Heal P, Tahtis K, Stewart LM and Bicknell R (2004) Soluble Robo4 receptor inhibits in vivo angiogenesis and endothelial cell migration. FASEB J. 19: 121-123

108. Howitt JA, Clout NJ and Hohenester E (2004) Binding site for Robo receptors revealed by dissection of the leucine-rich repeat region of Slit. EMBO J. 23: 4406-4412

109. Battye R, Stevens A, Perry RL and Jacobs JR (2001) Repellent signaling by Slit requires the leucine-rich repeats. J. Neurosci. 21: 4290-4298

110. Chen JH, Wen L, Dupuis S, Wu JY and Rao Y (2001) The N-terminal leucinerich regions in Slit are sufficient to repel olfactory bulb axons and subventricular zone neurons. J. Neurosci. 21: 1548-1556

111. Nguyen Ba-Charvet KT, Brose $\mathrm{K}$, Ma L, Wang KH, Marillat V, Sotelo $\mathrm{C}$, Tessier-Lavigne $M$ and Chedotal $A$ (2001) Diversity and specificity of actions of Slit2 proteolytic fragments in axon guidance. J. Neurosci. 21: 4281-4289

112. Xian J, Clark KJ, Fordham R, Pannell R, Rabbitts TH and Rabbitts PH (2001) Inadequate lung development and bronchial hyperplasia in mice with a targeted deletion in the Dutt1/Robo1 gene. Proc. Natl. Acad. Sci. USA 98: 15062-15066

113. Xian J, Aitchison A, Bobrow L, Corbett G, Pannell R, Rabbitts T and Rabbitts $P$ (2004) Targeted disruption of the 3p12 gene, Dutt1/Robo1, predisposes mice to lung adenocarcinomas and lymphomas with methylation of the gene promoter. Cancer Res. 64: 6432-6437

114. Hivert B, Liu Z, Chuang CY, Doherty P and Sundaresan V (2002) Robo1 and Robo2 are homophilic binding molecules that promote axonal growth. Mol. Cell. Neurosci. 21: 534-545

115. Liu Z, Patel K, Schmidt H, Andrews W, Pini A and Sundaresan V (2004) Extracellular Ig domains 1 and 2 of Robo are important for ligand (Slit) binding. Mol. Cell. Neurosci. 26: 232-240

116. Sundaresan V, Chung G, Heppell-Parton A, Xiong J, Grundy C, Roberts I, James L, Cahn A, Bench A, Douglas J, Minna J, Sekido Y, Lerman M, Latif F, Bergh J, Li H, Lowe N, Ogilvie D and Rabbitts P (1998) Homozygous deletions at $3 p 12$ in breast and lung cancer. Oncogene 17: 1723-1729

117. Wang B, Xiao Y, Ding BB, Zhang N, Yuan X, Gui L, Qian KX, Duan S, Chen Z, Rao $Y$ and Geng JG (2003) Induction of tumor angiogenesis by Slit-Robo signaling and inhibition of cancer growth by blocking Robo activity. Cancer Cell 4: 19-29

118. Latil $A$, Chene $L$, Cochant-Priollet $B$, Mangin $P$, Fournier $G$, Berthon $P$ and Cussenot $O(2003)$ Quantification of expression of netrins, slits and their receptors in human prostate tumors. Int. J. Cancer 103: 306-315

119. Dallol A, Da Silva NF, Viacava P, Minna JD, Bieche I, Maher ER and Latif $F$ (2002) SLIT2, a human homologue of the Drosophila Slit2 gene, has tumor suppressor activity and is frequently inactivated in lung and breast cancers. Cancer Res. 62: 5874-5880

120. Dallol A, Krex D, Hesson L, Eng C, Maher ER and Latif $F(2003)$ Frequent epigenetic inactivation of the SLIT2 gene in gliomas. Oncogene 22: 46114616

121. Dickinson RE, Dallol A, Bieche I, Krex D, Morton D, Maher ER and Latif F (2004) Epigenetic inactivation of SLIT3 and SLIT1 genes in human cancers. Br. J. Cancer 91: 2071-2078

122. Plump AS, Erskine L, Sabatier C, Brose K, Epstein CJ, Goodman CS, Mason CA and Tessier-Lavigne M (2002) Slit1 and Slit2 cooperate to prevent premature midline crossing of retinal axons in the mouse visual system. Neuron 33: 219-232

123. Wu JY, Feng L, Park HT, Havlioglu N, Wen L, Tang H, Bacon KB, Jiang Z, Zhang $X$ and Rao $Y$ (2001) The neuronal repellent Slit inhibits leukocyte chemotaxis induced by chemotactic factors. Nature 410: 948-952

124. Prasad A, Fernandis AZ, Rao Y and Ganju RK (2004) Slit protein-mediated inhibition of CXCR4-induced chemotactic and chemoinvasive signaling pathways in breast cancer cells. J. Biol. Chem. 279: 9115-9124

125. Nabeshima K, Shimao $Y$, Inoue $T$ and Sameshima $T$ (2002) Matrix metalloproteinases (MMP) in lung cancer. Nippon Rinsho. 60 (Suppl 5): 103-109

126. Nabeshima $K$, Inoue $T$, Shimao $Y$ and Sameshima $T$ (2002) Matrix metalloproteinases in tumor invasion: role for cell migration. Pathol. Int. 52: 255-264

127. Cajal Ry (1892) La rétine des vertébrés. La cellule 9: 121-133 
128. Lumsden AG and Davies AM (1986) Chemotropic effect of specific target epithelium in the developing mammalian nervous system. Nature 323: 538-539

129. Tessier-Lavigne M, Placzek M, Lumsden AG, Dodd J and Jessell TM (1988) Chemotropic guidance of developing axons in the mammalian central nervous system. Nature 336: 775-778

130. Serafini T, Kennedy TE, Galko MJ, Mirzayan C, Jessell TM and TessierLavigne M (1994) The netrins define a family of axon outgrowth-promoting proteins homologous to C. elegans UNC-6. Cell 78: 409-424

131. Van Raay TJ, Foskett SM, Connors TD, Klinger KW, Landes GM and Burn TC (1997) The NTN2L gene encoding a novel human netrin maps to the autosomal dominant polycystic kidney disease region on chromosome 16p13.3. Genomics 41: 279-282

132. Wang H, Copeland NG, Gilbert DJ, Jenkins NA and Tessier-Lavigne M (1999) Netrin-3, a mouse homolog of human NTN2L, is highly expressed in sensory ganglia and shows differential binding to netrin receptors. J. Neurosci. 19: 4938-4947

133. Yin Y, Sanes JR and Miner JH (2000) Identification and expression of mouse netrin-4. Mech. Dev. 96: 115-119

134. Zhang C, Meng F, Wang C, Guo H, Fan M, Liu S, Zhou R and He F (2004) Identification of a novel alternative splicing form of human netrin-4 and analyzing the expression patterns in adult rat brain. Brain Res. Mol. Brain Res. 130: $68-80$

135. Colamarino SA and Tessier-Lavigne M (1995) The axonal chemoattractant netrin-1 is also a chemorepellent for trochlear motor axons. Cell 81: 621-629

136. Murase $S$ and Horwitz AF (2002) Deleted in colorectal carcinoma and differentially expressed integrins mediate the directional migration of neural precursors in the rostral migratory stream. J. Neurosci. 22: 3568-3579

137. Yebra M, Montgomery AM, Diaferia GR, Kaido T, Silletti S, Perez B, Just ML, Hildbrand S, Hurford R, Florkiewicz E, Tessier-Lavigne M and Cirulli V (2003) Recognition of the neural chemoattractant Netrin-1 by integrins alpha6beta4 and alpha3beta1 regulates epithelial cell adhesion and migration. Dev. Cell 5: 695-707

138. Jiang Y, Liu MT and Gershon MD (2003) Netrins and DCC in the guidance of migrating neural crest-derived cells in the developing bowel and pancreas. Dev. Biol. 258: 364-384

139. Spassky N, de Castro F, Le Bras B, Heydon K, Queraud-LeSaux F, BlochGallego E, Chedotal A, Zalc B and Thomas JL (2002) Directional guidance of oligodendroglial migration by class 3 semaphorins and netrin-1. J. Neurosci. 22: 5992-6004

140. Tsai HH, Tessier-Lavigne M and Miller RH (2003) Netrin 1 mediates spinal cord oligodendrocyte precursor dispersal. Development 130: 2095-2105

141. Manitt C, Colicos MA, Thompson KM, Rousselle E, Peterson AC and Kennedy TE (2001) Widespread expression of netrin-1 by neurons and oligodendrocytes in the adult mammalian spinal cord. J. Neurosci. 21: 3911-3922

142. Leonardo ED, Hinck L, Masu M, Keino-Masu K, Ackerman SL and TessierLavigne M (1997) Vertebrate homologues of $C$. elegans UNC-5 are candidate netrin receptors. Nature $386: 833-838$

143. Engelkamp D (2002) Cloning of three mouse Unc5 genes and their expression patterns at mid-gestation. Mech. Dev. 118: 191-197

144. Corset V, Nguyen-Ba-Charvet KT, Forcet C, Moyse E, Chedotal A and Mehlen $\mathrm{P}$ (2000) Netrin-1-mediated axon outgrowth and cAMP production requires interaction with adenosine A2b receptor. Nature 407: 747-750

145. Shewan D, Dwivedy A, Anderson R and Holt CE (2002) Age-related changes underlie switch in netrin-1 responsiveness as growth cones advance along visual pathway. Nat. Neurosci. 5: 955-962

146. Patel BN and Van Vactor DL (2002) Axon guidance: the cytoplasmic tail. Curr. Opin. Cell Biol. 14: 221-229

147. Ackerman SL, Kozak LP, Przyborski SA, Rund LA, Boyer BB and Knowles BB (1997) The mouse rostral cerebellar malformation gene encodes an UNC-5like protein. Nature 386: 838-842

148. Przyborski SA, Knowles BB and Ackerman SL (1998) Embryonic phenotype of Unc5h3 mutant mice suggests chemorepulsion during the formation of the rostral cerebellar boundary. Development 125: 41-50

149. Hong K, Hinck L, Nishiyama M, Poo MM, Tessier-Lavigne M and Stein E (1999) A ligand-gated association between cytoplasmic domains of UNC5 and DCC family receptors converts netrin-induced growth cone attraction to repulsion. Cell 97: 927-941

150. Keleman $\mathrm{K}$ and Dickson BJ (2001) Short- and long-range repulsion by the Drosophila Unc5 netrin receptor. Neuron 32: 605-617
151. Keino-Masu K, Masu M, Hinck L, Leonardo ED, Chan SS, Culotti JG and Tessier-Lavigne M (1996) Deleted in Colorectal Cancer (DCC) encodes a netrin receptor. Cell 87: 175-185

152. Matsunaga E, Tauszig-Delamasure S, Monnier PP, Mueller BK, Strittmatter SM, Mehlen $\mathrm{P}$ and Chedotal A (2004) RGM and its receptor neogenin regulate neuronal survival. Nat. Cell Biol. 6: 749-755

153. Rajagopalan S, Deitinghoff L, Davis D, Conrad S, Skutella T, Chedotal A, Mueller BK and Strittmatter SM (2004) Neogenin mediates the action of repulsive guidance molecule. Nat. Cell Biol. 6: 756-762

154. Fearon ER, Cho KR, Nigro JM, Kern SE, Simons JW, Ruppert JM, Hamilton SR, Preisinger AC, Thomas G, Kinzler KW and Vogelstein B (1990) Identification of a chromosome $18 \mathrm{q}$ gene that is altered in colorectal cancers. Science 247: 49-56

155. Liu J, Yao F, Wu R, Morgan M, Thorburn A, Finley Jr RL and Chen YQ (2002) Mediation of the DCC apoptotic signal by DIP13 alpha. J. Biol. Chem. 277: 26281-26285

156. Kato HD, Kondoh $\mathrm{H}$, Inoue $\mathrm{T}$, Asanoma $\mathrm{K}$, Matsuda $\mathrm{T}$, Arima $\mathrm{T}$, Kato $\mathrm{K}$, Yoshikawa T and Wake N (2004) Expression of DCC and netrin-1 in normal human endometrium and its implication in endometrial carcinogenesis. Gynecol. Oncol. 95: 281-289

157. Arakawa $H(2004)$ Netrin-1 and its receptors in tumorigenesis. Nat. Rev. Cancer 4: 978-987

158. Thiebault K, Mazelin L, Pays L, Llambi F, Joly MO, Scoazec JY, Saurin JC, Romeo $\mathrm{G}$ and Mehlen $\mathrm{P}$ (2003) The netrin-1 receptors UNC5H are putative tumor suppressors controlling cell death commitment. Proc. Natl. Acad. Sci. USA 100: 4173-4178

159. Mehlen $P$ and Thibert $C$ (2004) Dependence receptors: between life and death. Cell. Mol. Life Sci. 61: 1854-1866

160. Mazelin L, Bernet A, Bonod-Bidaud C, Pays L, Arnaud S, Gespach C, Bredesen DE, Scoazec JY and Mehlen P (2004) Netrin-1 controls colorectal tumorigenesis by regulating apoptosis. Nature $431: 80-84$

161. Park KW, Crouse D, Lee M, Karnik SK, Sorensen LK, Murphy KJ, Kuo CJ and Li DY (2004) The axonal attractant Netrin-1 is an angiogenic factor. Proc. Natl. Acad. Sci. USA 101: 16210-16215

162. Lu X, Le Noble F, Yuan L, Jiang Q, De Lafarge B, Sugiyama D, Breant C, Claes F, De Smet F, Thomas JL, Autiero M, Carmeliet P, Tessier-Lavigne M and Eichmann A (2004) The netrin receptor UNC5B mediates guidance events controlling morphogenesis of the vascular system. Nature 432: 179186

163. Hanahan D and Folkman J (1996) Patterns and emerging mechanisms of the angiogenic switch during tumorigenesis. Cell 86: 353-364

164. Shirvan A, Kimron M, Holdengreber V, Ziv I, Ben-Shaul Y, Melamed S, Melamed E, Barzilai A and Solomon AS (2002) Anti-semaphorin 3A antibodies rescue retinal ganglion cells from cell death following optic nerve axotomy. J. Biol. Chem. 277: 49799-49807

165. Kikuchi K, Kishino A, Konishi O, Kumagai K, Hosotani N, Saji I, Nakayama C and Kimura $T$ (2003) In vitro and in vivo characterization of a novel semaphorin 3A inhibitor, SM-216289 or xanthofulvin. J. Biol. Chem. 278: 42985-42991

166. Song HJ and Poo MM (1999) Signal transduction underlying growth cone guidance by diffusible factors. Curr. Opin. Neurobiol. 9: 355-363

167. Tordjman R, Lepelletier Y, Lemarchandel V, Cambot M, Gaulard P, Hermine $\mathrm{O}$ and Romeo PH (2002) A neuronal receptor, neuropilin-1, is essential for the initiation of the primary immune response. Nat. Immunol. 3: 477-482

168. Guan H, Zu G, Xie Y, Tang H, Johnson M, Xu X, Kevil C, Xiong WC, Elmets C, Rao Y, Wu JY and Xu H (2003) Neuronal repellent Slit2 inhibits dendritic cell migration and the development of immune responses. J. Immunol. 171: 65196526

169. Ohta K, Mizutani A, Kawakami A, Murakami Y, Kasuya Y, Takagi S, Tanaka H and Fujisawa $H$ (1995) Plexin: a novel neuronal cell surface molecule that mediates cell adhesion via a homophilic binding mechanism in the presence of calcium ions. Neuron 14: 1189-1199

170. Stein $E$ and Tessier-Lavigne $M(2001)$ Hierarchical organization of guidance receptors: silencing of netrin attraction by slit through a Robo/DCC receptor complex. Science 291: 1928-1938

171. Miyashita T, Yeo SY, Hirate Y, Segawa H, Wada H, Little MH, Yamada T, Takahashi $\mathrm{N}$ and Okamoto $\mathrm{H}$ (2004) PlexinA4 is necessary as a downstream target of Islet2 to mediate Slit signaling for promotion of sensory axon branching. Development 131: 3705-3715 